Article

\title{
Aging of Podospora anserina Leads to Alterations of OXPHOS and the Induction of Non-Mitochondrial Salvage Pathways
}

\author{
Verena Warnsmann ${ }^{1}\left(\mathbb{D}\right.$, Jana Meisterknecht ${ }^{2}$, Ilka Wittig ${ }^{2}$ and Heinz D. Osiewacz ${ }^{1, *(\mathbb{D})}$ \\ 1 Institute of Molecular Biosciences, Faculty of Biosciences, Goethe-University, Max-von-Laue-Str. 9, \\ 60438 Frankfurt, Germany; warnsmann@bio.uni-frankfurt.de \\ 2 Functional Proteomics, Institute of Cardiovascular Physiology, Faculty of Medicine, Goethe-University, \\ Theodor-Stein-Kai 7, 60590 Frankfurt am Main, Germany; meisterknecht@em.uni-frankfurt.de (J.M.); \\ wittig@med.uni-frankfurt.de (I.W.) \\ * Correspondence: osiewacz@bio.uni-frankfurt.de
}

check for updates

Citation: Warnsmann, V.; Meisterknecht, J.; Wittig, I.; Osiewacz, H.D. Aging of Podospora anserina Leads to Alterations of OXPHOS and the Induction of Non-Mitochondrial Salvage Pathways. Cells 2021, 10, 3319. https://doi.org/10.3390/ cells10123319

Academic Editors: Milena Georgieva and Mateusz Mołoń

Received: 2 November 2021

Accepted: 24 November 2021

Published: 26 November 2021

Publisher's Note: MDPI stays neutral with regard to jurisdictional claims in published maps and institutional affiliations.

Copyright: (c) 2021 by the authors. Licensee MDPI, Basel, Switzerland. This article is an open access article distributed under the terms and conditions of the Creative Commons Attribution (CC BY) license (https:/ / creativecommons.org/licenses/by/ $4.0 /)$.

\begin{abstract}
The accumulation of functionally impaired mitochondria is a key event in aging. Previous works with the fungal aging model Podospora anserina demonstrated pronounced age-dependent changes of mitochondrial morphology and ultrastructure, as well as alterations of transcript and protein levels, including individual proteins of the oxidative phosphorylation (OXPHOS). The identified protein changes do not reflect the level of the whole protein complexes as they function in-vivo. In the present study, we investigated in detail the age-dependent changes of assembled mitochondrial protein complexes, using complexome profiling. We observed pronounced age-depen-dent alterations of the OXPHOS complexes, including the loss of mitochondrial respiratory supercomplexes (mtRSCs) and a reduction in the abundance of complex I and complex IV. Additionally, we identified a switch from the standard complex IV-dependent respiration to an alternative respiration during the aging of the P. anserina wild type. Interestingly, we identified proteasome components, as well as endoplasmic reticulum (ER) proteins, for which the recruitment to mitochondria appeared to be increased in the mitochondria of older cultures. Overall, our data demonstrate pronounced age-dependent alterations of the protein complexes involved in energy transduction and suggest the induction of different non-mitochondrial salvage pathways, to counteract the age-dependent mitochondrial impairments which occur during aging.
\end{abstract}

Keywords: Podospora anserina; aging; OXPHOS; complexome profiling

\section{Introduction}

Biological aging is commonly described as a process associated with the time-dependent decline of physiological functions and the accumulation of cellular and molecular damage [1-3]. Over decades of research, mitochondria have been demonstrated to play a central role in aging [4-9]. These organelles are involved in a number of essential cellular processes, including the synthesis of iron/sulfur clusters, amino acid, lipids, and in energy transduction leading to the production of ATP. A network of pathways involved in maintenance of a population of intact mitochondria is effective and counteracts the time-dependent accumulation of functionally impaired mitochondria [10,11].

One model organism with a strong mitochondrial etiology of aging is the ascomycete Podospora anserina [12-14]. This filamentous fungus is characterized by a limited lifespan. Starting from a single ascospore, the product of sexual reproduction, a vegetation body (mycelium) develops that consists of branched filamentous cells (hyphae), which grow at their tips. After a strain-specific linear growth period of a few weeks, the growth rate of the mycelium slows down. Finally, growth ceases and the hyphal tips burst $[15,16]$. During aging of $P$. anserina the mitochondria undergo pronounced morphological and ultrastructural changes. In juvenile hyphae, the mitochondria occur as a network of filamentous organelles. Due to an altered balance of the mitochondrial fusion and fission, the network 
disintegrates during aging, leading to punctuated mitochondria [17]. At the ultrastructural level, the typical lamellar cristae ultrastructure changes and forms vesicles $[18,19]$. This age-dependent structural reorganization is concurrent with the dissociation of $\mathrm{F}_{1} \mathrm{~F}_{\mathrm{o}}$-ATP synthase dimers [20]. Recently, intervention in the $\mathrm{F}_{1} \mathrm{~F}_{\mathrm{o}}$-ATP-synthase dimerization process, via the ablation of the $\mathrm{F}_{1} \mathrm{~F}_{\mathrm{o}}$-ATP-synthase assembly factor PaATPE, experimentally supported this scenario. The PaAtpe deletion mutant displays a vesicular mitochondrial ultrastructure and impairments in mitochondrial function and is short-lived, due to a detrimental induction of mitophagy [21,22]. Age-dependent fragmentation of mitochondria and reorganization of the inner membrane were also reported for other organisms, from yeast to humans $[17,23-28]$.

In P. anserina, the age-related changes in mitochondrial morphology and ultrastructure go along with a pronounced reorganization of the mitochondrial DNA (mtDNA), which encodes a number of essential proteins of the respiratory chain [29-33]. Stabilization of the mtDNA by various means was shown to extend lifespan [34-37]. These data suggested an important role of mitochondrial respiration in the aging process of $P$. anserina and this was found to be evolutionary conserved [7,38-40]. Aging was further linked to mitochondrial impairments, such as reduction of the capacity of the oxidative phosphorylation (OXPHOS) at the respiratory chain and, thus, an age-dependent decrease of respiration [24,41-44]. A variety of studies with P. anserina further supported the impact of respiration on aging and lifespan. For instance, impairments of the standard complex IV (cytochrome-c-oxidase; COX)-dependent respiration in different $P$. anserina mutants led to the induction of an alternative oxidase (AOX)-dependent respiration and an increased lifespan $[36,37,45,46]$. This increase is concomitant with a reduction of the generation of the superoxide anion as a reactive oxygen species (ROS) [46]. Details about the role of ROS in the aging of $P$. anserina were discussed in a recent review [14]. A general role of ROS, which to a large extend are generated at the mitochondrial respiratory chain, and aging is evolutionary conserved from yeast to humans and is the kernel of the 'mitochondrial free radical theory of aging' [5]. Molecular impairments in respiration are known to increase oxidative stress and contribute to the aging process $[14,47,48]$. A detailed understanding of the structure and function of the respiratory machinery is therefore of paramount relevance for understanding biological aging. The respiratory chain consists of five individual complexes (complex I-V), which can assemble into different supercomplexes, the so-called mitochondrial respiratory supercomplexes (mtRSC) [49]. Individual OXPHOS complexes and mtRSCs exist side by side in the inner mitochondrial membrane $[50,51]$. In addition, in P. anserina, such a structure was previously demonstrated [52]. The manipulation of the composition of the respiratory chain was shown to have a strong impact on lifespan. For instance, disruption of mitochondrial respiratory supercomplex (mtRSC) assembly by ablation of PaRCF1 and PaRCF2, two mtRSC assembly factors, leads to lifespan shortening [53]. Recently, a study of the P. anserina $\mathrm{F}_{1} \mathrm{~F}_{\mathrm{O}}$-ATP synthase revealed hints at an age-dependent alteration of the respiratory chain composition and loss of mtRSCs [21]. Moreover, the pronounced lifespan-extending effect in a mutant deleted for the gene coding for the mitochondrial PaIAP protease was found to be linked to an increase in mtRSCs [54].

In the past, a number of studies focused on age-dependent changes in mitochondrial transcript and protein levels in different biological systems, including P. anserina. A longitudinal transcriptome analysis revealed that the transcript profiles associated with mitochondrial function fluctuate during the aging of $P$. anserina [55]. This fluctuation has also been studied on the protein level in P. anserina, but mainly with the soluble protein part of mitochondria and a focus on protein modifications [56-58]. Only one study addressed both soluble and membrane-integral mitochondrial proteins and demonstrated age-dependent changes of some individual mitochondrial proteins associated with the OXPHOS [59]. However, in none of these studies was special care taken to prepare and analyze protein complexes and, thus, they do not provide information about alterations at the level of whole protein complexes. 
Here we report results from a complexome profiling analysis, in which high molecular weight protein complexes were separated using BN-PAGE, subsequently sliced into even fractions, and analyzed by quantitative mass spectrometry [60-62]. The identified proteins were quantified and their appearance in high molecular weight regions could be visualized as interaction profiles, using heatmaps [63]. Here, the comparison of the resulting profiles of two mitochondrial samples, from two different age stages of the P. anserina wild type, uncovered detailed age-dependent alterations of the mitochondrial complexome. We also observed an age-associated switch from a standard complex IV-dependent, to an AOXdependent, respiration in the $P$. anserina wild type. Most strikingly, we identified that components of the proteasome, as well as the endoplasmic reticulum (ER) proteins, had an increased abundance of enriched mitochondrial fractions of older strains, suggesting the induction of compensatory salvage pathways occurs during aging.

\section{Materials and Methods}

\subsection{P. anserina Strains and Cultivation}

In this study, the P. anserina wild-type strain ' $\mathrm{s}$ ' [64] was used. The strain was grown on standard cornmeal agar (BMM) at $27^{\circ} \mathrm{C}$ under constant light [65]. For all analyses in this study, strains derived from monokaryotic ascospores were used [65]. These spores were isolated from defined crosses. For germination, spores were incubated on standard cornmeal agar (BMM) with $60 \mathrm{mM}$ ammonium acetate (Merck, Darmstadt, Germany; 1116.1000) at $27^{\circ} \mathrm{C}$ in the dark for 2 days. To obtain cultures with a defined age, a piece of germinated mycelium was placed at one site of a M2 agar plate and incubated for the desired time (i.e., 6 or 18 days) at $27^{\circ} \mathrm{C}$ under constant light.

\subsection{Isolation of Mitochondria}

P. anserina wild-type strains were grown on cellophane foil covered M2 agar plates under constant light at $27^{\circ} \mathrm{C}$. After two days of growth, mycelia were transferred to CMliquid medium and incubated for an additional two days at $27^{\circ} \mathrm{C}$, in constant light and shaking. The mitochondria of young $(6 \mathrm{~d})$ and old $(18 \mathrm{~d})$ P. anserina wild-type cultures were isolated, according to a published protocol [46]. For purification of mitochondria a discontinuous sucrose gradient $(20-36-50 \%)$ and ultracentrifugation $(100,000 \times g)$ was used [65].

\subsection{Blue Native Gel Electrophoresis (BN-PAGE)}

BN-PAGE was performed, to separate native protein complexes according to size, as described [66,67]. Briefly, $150 \mu \mathrm{g}$ of isolated mitochondria (mitochondria from two independently isolations were pooled) were solubilized with digitonin (Sigma-Aldrich, St. Louis, MO, USA; D141) at a detergent/protein ratio of $4 \mathrm{~g} / \mathrm{g}$. Solubilized mitochondria were centrifuged at $4{ }^{\circ} \mathrm{C}$ for $30 \mathrm{~min}$ at $20,000 \times \mathrm{g}$. The obtained supernatants were immediately loaded on a linear gradient gel (4-13\%) overlaid with 3.5\% stacking gel. Electrophoresis was started at $100 \mathrm{~V}$ and $10 \mathrm{~mA}$. When samples had completely migrated into the stacking gel, limits were set to $500 \mathrm{~V}$ and $15 \mathrm{~mA}$. Electrophoresis was stopped when the Coomassie front approached the gel front. After electrophoresis, the gel was incubated for $30 \mathrm{~min}$ in fixing solution (50\% methanol (Carl Roth, Karlsruhe, Germany; 4627.5), 10\% acetic acid (Carl Roth, Karlsruhe, Germany; 3738.5), 100 mM ammonium acetate (Merck, Darmstadt, Germany; 1116.1000), and subsequently proteins were visualized after 1-h Coomassie staining ( $0.025 \%$ Coomassie blue-G 250 (Carl Roth, Karlsruhe, Germany; 9598.2) in 10\% acetic acid (Carl Roth, Karlsruhe, Germany; 3738.5). Afterwards the gel was destained with water and $10 \%$ acetic acid.

\subsection{Western Blot Analysis}

Mitochondrial protein extracts $(50 \mu \mathrm{g})$ were separated by 2-phase SDS-PAGE (12\% separating gels) according to the protocol published in Brust et al. [18]. Briefly, after electrophoresis of mitochondrial protein extracts, proteins were transferred to PVDF mem- 
branes using the Trans-Blot ${ }^{\circledR}$ Turbo $^{\text {TM }}$ transfer system (BIO-RAD, Hercules, CA, USA), according to the manufacturer's specifications. Afterwards, blocking, antibody incubation, and washing steps were performed according to the Odyssey 'Western Blot Analysis' handbook (LI-COR Biosciences, Bad Homburg, Germany). As primary antibody, an antiPaAOX1 (rabbit, 1:5000 diluted, raised against synthetic peptide NHKEDPNPFVSDYKCDADHQR, Davids Biotechnologie GmbH, Regensburg, Germany) was used. Subsequently, a conjugated IR Dye CW 800 (1:15,000 dilution, goat anti-rabbit 800: LIC-OR Biosciences, Bad Homburg, Germany; 926-32211) was used as secondary antibody. For detection, an Odyssey ${ }^{\circledR}$ Fc imaging system (LI-COR Biosciences, Bad Homburg, Germany) was used, and densitometric quantification was performed with the manufacturer's software, Image Studio 5.2 .

\subsection{Mitochondrial Oxygen Consumption}

Determination of COX- and AOX-dependent oxygen consumption was performed using strains cultivated on M2 medium for 2 days and in CM liquid medium for 2 days, as described above. Small pieces of mycelium were subsequently transferred into the highresolution respirometer (Oxygraph-2k series C and G, Oroboros Instruments, Innsbruck, Austria) and oxygen consumption was measured in liquid $\mathrm{CM}$ medium according to the manufacturer's instructions. Then, $1 \mathrm{mM}$ potassium cyanide $(\mathrm{KCN}$; Fluka, Buchs, Switzerland; 60178) was added to inhibit respiration via COX, and $4 \mathrm{mM}$ salicylhydroxamic acid (SHAM; Sigma-Aldrich, St. Louis, MO, USA; S607) was added to inhibit respiration via AOX. Data were analyzed using the manufacturer's software DatLab 6.

\subsection{Complexome Profiling}

Complexome profiling was used to identify native protein complexes after BN-PAGE and their alterations during aging. It was performed as published previously [61]. In brief, $150 \mu \mathrm{g}$ isolated mitochondria (mitochondria from two independent isolations were pooled), solubilized, and separated by BN-PAGE, as described above in the BN-PAGE section. After native electrophoresis, blue-native gels were fixed in 50\% $(v / v)$ methanol (Thermo Fisher Scientific, Waltham, MA, USA; 11976961), 10\% ( $v / v)$ acetic acid (Merck, Darmstadt, Germany; 33209), and $10 \mathrm{mM}$ ammonium acetate (Merck, Darmstadt, Germany; 1116.1000) for $30 \mathrm{~min}$ and stained with Coomassie $(0.025 \%$ Serva Blue G (SERVA, Heidelberg, Germany, 35050) and 10\% (v/v) acetic acid (Merck, Darmstadt, Germany; 33209)). Afterwards, each lane of the gel was cut from the bottom to the top into 48 almost equal fractions. Fractions were collected in 96 filter well plates (30-40 $\mu \mathrm{m}$ PP/PE, Pall Corporation). The gel pieces were destained in $60 \%$ Methanol, $50 \mathrm{mM}$ ammonium bicarbonate (ABC) (Merck, Darmstadt, Germany; V900254). Solutions were removed by centrifugation for $2 \mathrm{~min}$ at $600 \times$ g. Proteins were reduced in 10 mM DTT (Merck, Darmstadt, Germany; D9779) and $50 \mathrm{mM}$ ABC (Merck, Darmstadt, Germany; V900254) for one hour at $56^{\circ} \mathrm{C}$ and alkylated for $45 \mathrm{~min}$ in $30 \mathrm{mM}$ iodoacetamid (Merck, Darmstadt, Germany; I1149). Samples were digested for $16 \mathrm{~h}$ with trypsin (Promega, Fitchburg, WI, USA; V5111), at $37^{\circ} \mathrm{C}$ in $50 \mathrm{mM}$ ABC (Merck Darmstadt, Germany; V900254), 0.01\% Protease Max (Promega, Fitchburg, WI, USA; V2072), and $1 \mathrm{mM} \mathrm{CaCl}_{2}$ (Merck, Darmstadt, Germany; C3306). Peptides were eluted in 30\% acetonitrile (VWR, Radnor, PA, USA; 83640) and 3\% formic acid (VWR, Radnor, PA, USA; 85048), centrifuged into a fresh 96 well plate, dried in a speed vac, and resolved in $1 \%$ acetonitrile and $0.5 \%$ formic acid.

Liquid chromatography/mass spectrometry (LC/MS) was performed on a Thermo Scientific ${ }^{\mathrm{TM}} \mathrm{Q}$ Exactive Plus equipped with an ultra-high-performance liquid chromatography unit (Thermo Scientific Dionex Ultimate 3000) and a Nanospray Flex Ion-Source (Thermo Scientific). Peptides were loaded on a C18 reversed-phase precolumn (Thermo Scientific), followed by separation with a $2.4 \mu \mathrm{m}$ Reprosil C18 resin (Dr. Maisch GmbH) inhouse packed picotip emitter tip (diameter $100 \mu \mathrm{m}, 15 \mathrm{~cm}$ from New Objectives), separated using a gradient from $4 \%$ acetonitrile, $0.1 \%$ formic acid, to $30 \%$ eluent B (99\% acetonitrile, $0.1 \%$ formic acid) for $30 \mathrm{~min}$ and an additional gradient to $60 \%$ for $5 \mathrm{~min}$ with a flow rate 
$400 \mathrm{~nL} / \mathrm{min}$ and washout with $99 \% \mathrm{~B}$ for $5 \mathrm{~min}$. MS data were recorded by data-dependent acquisition. The full MS scan range was 300 to $2000 \mathrm{~m} / z$, with a resolution of 70,000 and an automatic gain control (AGC) value of 3E6 total ion counts, with a maximal ion injection time of $160 \mathrm{~ms}$. Only higher charged ions (2+) were selected for MS/MS scans with a resolution of 17,500, an isolation window of $2 \mathrm{~m} / z$, and an automatic gain control value set to E5 ions, with a maximal ion injection time of $150 \mathrm{~ms}$. MS1 data were acquired in profile mode.

MS data were analyzed using MaxQuant (v 2.0.1.0) [68] and the default settings. Proteins were identified using the P. anserina proteome database UniProtKB with 10657 entries, released in $8 / 2021$. The enzyme specificity was set to trypsin. Acetylation $(+42.01)$ at the $n$-terminus and oxidation of methionine $(+15.99)$ were selected as variable modifications, and carbamidomethylation (+57.02) as fixed modification on cysteines. The false discovery rate (FDR) for the identification protein and peptides was $1 \%$. Intensity-based absolute quantification (IBAQ) values were recorded. The sum of all IBAQ values of data sets were normalized to data of the 18-day-old sample. Protein abundance within native lanes were normalized to the maximum appearance, to enable comparison of mitochondrial complexes between samples. Slice number, according to a native mass ladder, was used for native mass calibration. The software NOVA (v.0.5.7) was used for hierarchical clustering of complexomics data [69].

\section{Results and Discussion}

\subsection{Aging in P. anserina Leads to Changes in the Composition of the Respiratory Chain}

The pronounced age-associated reorganization of the mtDNA of P. anserina, resulting in the deletion of large parts of the mtDNA, suggested that severe changes of the mitochondrial transcriptome and proteome occur during aging [29-33]. Subsequent studies verified this assumption [55-59]. For instance, the transcript and protein level of mitochondrialencoded OXPHOS subunits such as PaCOX1 (Pa_mito_cox1), PaCOX2 (Pa_mito_cox2), and PaND4 (Pa_mito_nad4) clearly decline during aging. Obviously, such alterations impinge on the abundance of the individual OXPHOS complexes and subsequently on the level of the mtRSCs. Accordingly, in older cultures a decreased abundance of mtRSCs compared to young cultures was found [21].

In the current study, we aimed to focus on a comprehensive analysis of the agerelated mitochondrial complexome [60-62]. For this analysis we isolated mitochondria from 6-day- and 18-day-old $P$. anserina wild-type cultures. The older age-stage lies in the range were the first cultures of a population died (Figure 1A). After solubilization with the mild detergent digitonin, the mitochondrial proteins (each sample was pooled from mitochondria of two different cultures) were separated by BN-PAGE. In the case of the 6-day-old sample, we obtained the typical and well-known pattern of OXPHOS complexes [52,70]. Coomassie staining visualizes complex I (NADH dehydrogenase), complex III (cytochrome c reductase), and complex IV (cytochrome oxidase; COX), as well as monomeric and dimeric complex $\mathrm{V}\left(\mathrm{F}_{1} \mathrm{~F}_{\mathrm{O}}\right.$-ATP-synthase). Furthermore, all three known mtRSCs, $S_{0}, S_{1}$, and $S_{2}$, which consist of $\mathrm{CI}_{1} \mathrm{CIII}_{2} \mathrm{CIV}_{0}, \mathrm{CI}_{1} \mathrm{CIII}_{2} \mathrm{CIV}_{1}$, and $\mathrm{CI}_{1} \mathrm{CIII}_{2} \mathrm{CIV}_{2}$, respectively, were visible (Figure 1B). In agreement with a previous study [21] mtRSCs were strongly reduced or partly lost in the 18-day-old sample. A comparable alteration of mtRSCs was also found in the mitochondria of aged rat cells [71,72]. Furthermore, a reduction of monomeric complex $\mathrm{I}\left(\mathrm{I}_{1}\right)$ and monomeric complex IV $\left(\mathrm{IV}_{1}\right)$ occurred, suggesting a reduced activity of these complexes in aged cultures. Such a reduced activity of complex I and complex IV was found in aged rodents [73-75].

Next, 48 equal pieces (Figure 1C) of the BN-PAGE from each of the two samples were fractionated and subjected to a quantitative mass spectrometry analysis. Identified proteins were clustered according to their abundance profile across all fractions (Table S1A), and a soluble mass ladder (Figure 1B, Table S1B) was used for native mass calibration of complexome data (Table S1B). Overall, 1314 unique proteins were identified (Table S1A). Many of the clustered proteins form parts of well-studied protein complexes, such as the 
five protein complexes of the OXPHOS system. We focused our attention on the OXPHOS complexes and on other yet unstudied major complexes with an altered abundance in the two mitochondrial samples from cultures of different age.

A

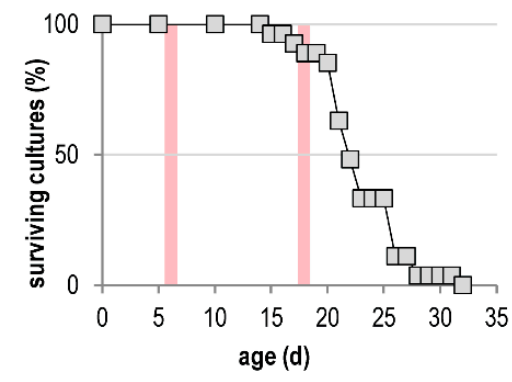

B

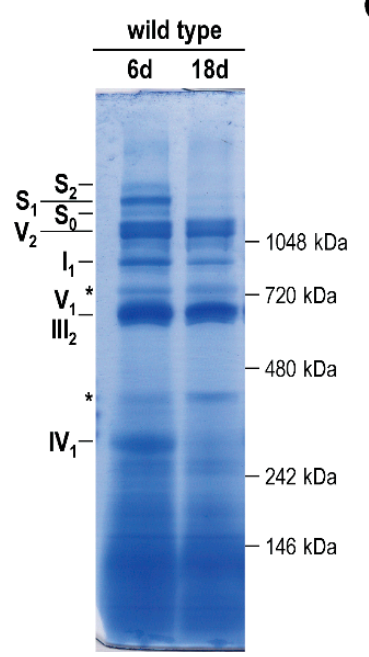

C

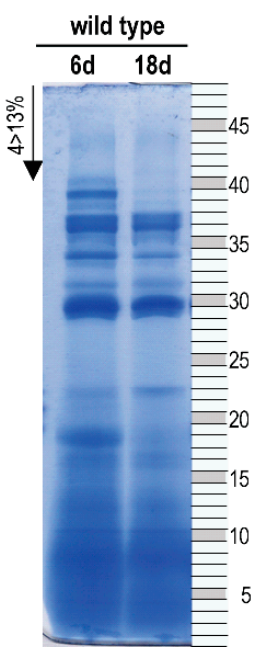

Figure 1. Age-dependent reduction of respiratory chain complexes. (A) Survival curve of $P$. anserina wild type $(n=15)$ grown on M2 medium under standard growth conditions. Red bars mark the time points used for further investigations. (B) BN-PAGE analysis of isolated mitochondria from 6-day- and 18-day-old wild-type cultures (each sample was pooled from the mitochondria of two different cultures). Mitochondria were solubilized with digitonin (ratio: digitonin to protein $4 \mathrm{~g} / \mathrm{g}$ ). The $\mathrm{CI}_{1} \mathrm{CIII}_{2} \mathrm{CIV}_{0-2}\left(\mathrm{~S}_{0-2}\right)$ supercomplexes, dimeric complexes III and $\mathrm{V}\left(\mathrm{III}_{2}\right.$ and $\left.\mathrm{V}_{2}\right)$, as well as monomeric complexes $\mathrm{I}_{1}, \mathrm{IV}_{1}$, and $\mathrm{V}_{1}$ were visualized using Coomassie staining. Asterisks ${ }^{*}$ ) mark uncharacterized protein bands. (C) For complexome profiling the BN-PAGE lanes were cut horizontally from the lower to the upper site in 48 , almost equally sized, pieces. The numbers of the single fractions are indicated on the right.

To reveal age-dependent changes in the OXPHOS, we generated a heat map and compared the distribution profiles of both age stages (Figure 2). An age-related reduction of mtRSCs is clearly seen in the decreased abundance of proteins belonging to complex I, complex III, and complex IV in fractions 38 to 40 (mass range $1200 \mathrm{kDa}$ up to $1600 \mathrm{kDa}$ ) (Figure 2A). This is in good agreement with previously published data obtained in an analysis about the role of $\mathrm{F}_{1} \mathrm{~F}_{\mathrm{o}}$-ATP-synthase dimers in the aging of P. anserina [21]. Such an age-dependent reduction of mtRSCs was also observed in different rat tissues [71,72]. In cardiac mitochondria from aged rats, it was demonstrated that the mtRSCs with the highest molecular masses were diminished [72]. Additionally, in mitochondria from the brain cortex of aged rats, a loss of mtRSCs stability was described [71]. Furthermore, mtRSCs play a role in various human diseases, such as Barth syndrome, heart failure, and Parkinson's disease [76-79]. In addition to changes in mtRSC abundance, we observed changes in the individual complexes of the OXPHOS. Particularly, the abundance of complex I subunits was reduced from 6-day-old to 18-day-old samples in fractions 33 and 34 (position of individual complex I at $\sim 900 \mathrm{kDa}$ ) (Figure $2 \mathrm{~A}, \mathrm{~B}$ ). A more detailed evaluation of these changes follows in a subsequent section. The total abundance of complex III did not change (Table S1C). Instead, during aging, complex III containing mtRSCs disintegrated into individual complex III dimers (Figure 2A,C). Similarly to complex I, the amount of complex IV was reduced in older cultures (Figure 2D). The age-dependent dissociation of the complex IV-containing mtRSCs should instead increase the amount of complex IV monomer. However, the amount of monomeric complex IV was much lower, suggesting additional reasons for the loss of this complex and supercomplexes (Figure 2D). Minor alterations were observed in complex II (Figure 2A,E). Here, the total amount of individual subunits was not affected. In contrast to the other complexes, complex $\mathrm{V}$ exists in a 
monomeric $\left(\mathrm{V}_{1}\right)$, as well as in a dimeric $\left(\mathrm{V}_{2}\right)$, state [70]. An age-related dissociation of complex V dimers, as described in earlier studies [20,21], was not observed in the current analysis (Figure 2A,F). However, due to the use of different cultivation media, the cultures in the previous study were physiologically older than in the current study, suggesting that the dissociation of complex $\mathrm{V}$ dimers may occur at the end of life. Interestingly, some subunits of complex $\mathrm{V}$ were found in lower fractions with an increased abundance in the older sample (lower panel of Figure 2A). These subunits are part of the $\mathrm{F}_{1}$ domain of complex $\mathrm{V}$, indicating an imbalanced assembly of $\mathrm{F}_{1}$ and $\mathrm{F}_{\mathrm{O}}$ domains (Figure $2 \mathrm{~F}$ ).

A
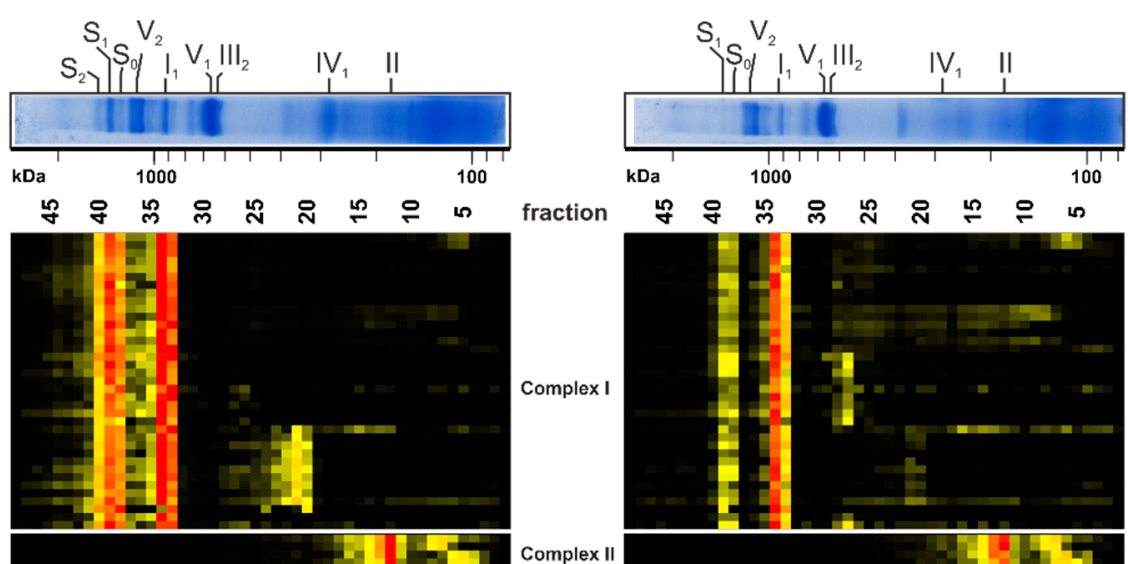

fraction
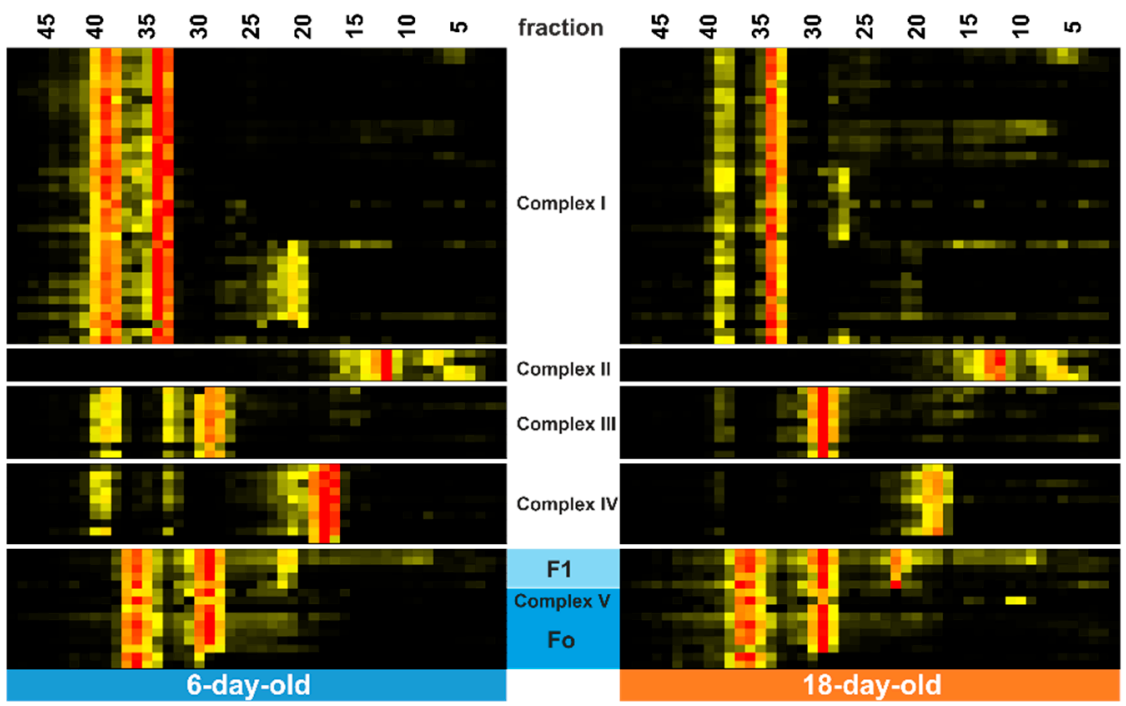

\section{B}
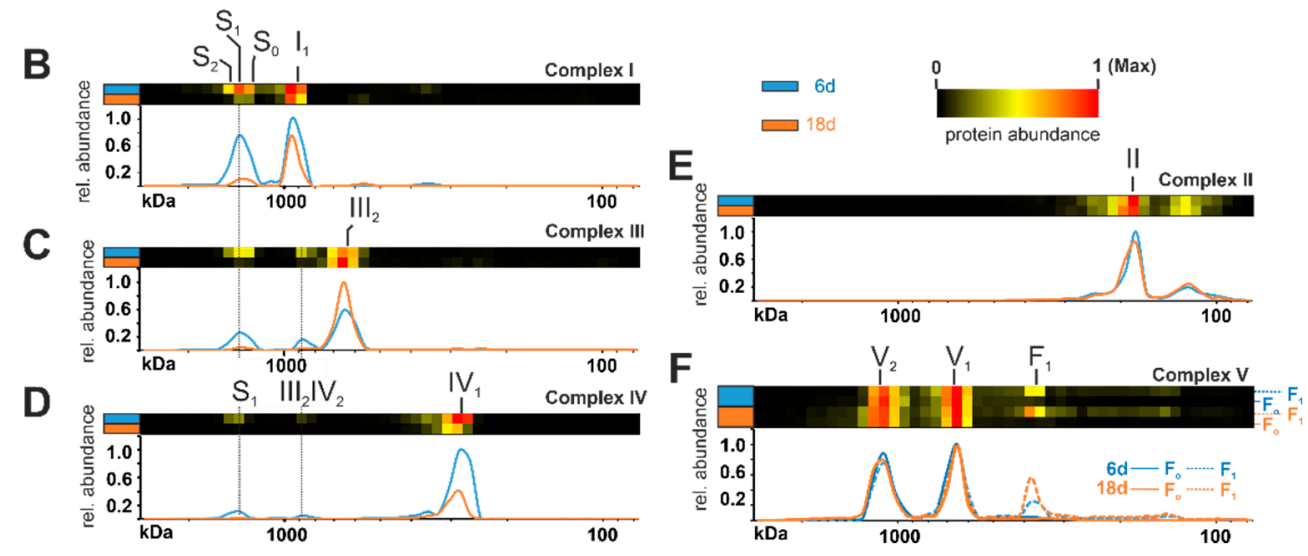

Figure 2. Age-dependent changes of respiratory chain complexes. (A) Identified subunits of all complexes of the oxidative phosphorylation system are represented in a heat map. The relative abundances were normalized to the maximum value within each lane. The color scale ranges from black (not identified), to yellow (20\% of the maximum in (A), $15 \%$ in $(\mathbf{B}-\mathbf{F})$ ), to red (maximum abundance). For detailed information about the corresponding proteins refer to Table S1C. Heatmaps of a combination of all respiratory chain complexes and visualization in 2D profiles for (B) complex I, (C) complex III (D) complex IV, and (E) complex II. (F) Complex V (ATP synthase) with the appearance of $\mathrm{F}_{1}$ and $\mathrm{F}_{\mathrm{o}}$ domains.

Overall, these data identified clear age-dependent alterations of OXPHOS in P. anserina, which ultimately must lead to impaired mitochondrial function. 
3.1.1. The Alternative NADH Dehydrogenases PaNDI1 Counterbalances Complex I Deficiency during Aging

Next, we investigated complex I in more detail (Figure 3A). This complex consists of several subunits with seven mitochondrial- and more than 34 nuclear-encoded; although the complete list of all complex I subunits is still not known. In the complexome dataset, a total of 37 subunits, with five being mitochondrial-encoded, were detected $(*$, Figure $3 \mathrm{~A})$. In total, we observed a reduced amount of complex I in the older P. anserina wild-type cultures (Figures 2B and 3A, Table S1D). Noticeably, several complex I subunits are rarely found in fractions under $500 \mathrm{kDA}$ (fraction 25 and lower). Different studies demonstrated a modular structure and stepwise assembly of complex I via different intermediates [60,80-83]. Intermediates were identified and more closely characterized in complexome profiling of Arabidopsis thaliana [84] and human cell cultures [81]. Subunits of the structural modules (Figure 3) were sorted according to their homologs in mammals and Yarrowia lipolytica, and listed in Table S1D [85]. In contrast to complexome profiling data from mammals, P. anserina exhibited an accumulation of distal membrane arm domains, with a size of $300-500 \mathrm{kDa}$, in the 6-day-old sample. It remains unclear if this subcomplex is a preassembly or the breakdown product of a complex I disassembly during maintenance. The latter was recently suggested in mammalian mitochondria, where a maintenance pathway for complex I was described [86,87].

Interestingly, this membrane arm subcomplex was not accumulated in the 18-day-old samples, indicating that this module is not in stock and assembly or maintenance was delayed. On the other hand, the 18-day-old sample accumulated the proximal part of the proton pumping module (Figure 3A). Little is known about assembly factors in P. anserina. None of the identified homologs to human assembly factors had clearly migrated together with the accumulated membrane arm intermediates (Figure 3B, Table S1D). Two subunits (Pa_1_16630 and Pa_2_5150) could not be assigned to any known homolog of complex I subunits. Both proteins shared a migration through the native gel with subunits assigned to the proximal proton pumping module, suggesting their structural location (Figure $3 \mathrm{~A}$, arrows).

Under standard growth conditions, complex I-dependent NADH oxidation is coupled with proton-pumping. In plants and fungi, this oxidation can also occur through another family of proteins. These so-called alternative NADH dehydrogenases oxidize NADH from the cytosol (external enzymes) or from the mitochondrial matrix (internal enzymes) without proton pumping [88]. In the yeast Saccharomyces cerevisiae, which lacks complex I, three alternative NADH dehydrogenases, one internal and two external enzymes, have been well characterized $[89,90]$. However, some organisms with complex I also possess alternative NADH dehydrogenases. In P. anserina the three alternative NADH dehydrogenases, PaNDI1 (internal, Pa_7_1820), PaNDE1 (external, Pa_1_24200), and PaNDE2 (external, Pa_7_5390), are active [46,91]. A previous study showed that PaNDI1 acts as a molecular bypass to restore the physiological consequences of complex I deficiency in $P$. anserina mutants. Interestingly, both external NADH dehydrogenases are not able to compensate complex I deficiency in P. anserina [91]. Furthermore, expression of NDI1 from S. cerevisiae partially restores complex I deficiencies in other organisms, such as worms and mice, and in human cell lines [92-96]. Whether the induction of alternative NADH dehydrogenases plays a role during aging has not been analyzed so far. Our current data demonstrate an age-dependent reduction of both external NADH dehydrogenases PaNDE1 and PaNDE2 (Figure 3C), whereas the internal NADH dehydrogenases PaNDI1 showed an increased abundance in the older sample (Figure 3C,D). We assume that PaNDI1 is induced as a compensatory mechanism, to overcome the age-associated reduction of complex I, and prevents an over-reduction of the $\mathrm{NAD}^{+} / \mathrm{NADH}$ pool in the mitochondrial matrix. Altogether, this is the first hint at a role of PaNDI1 in the aging process of $P$. anserina. 
A
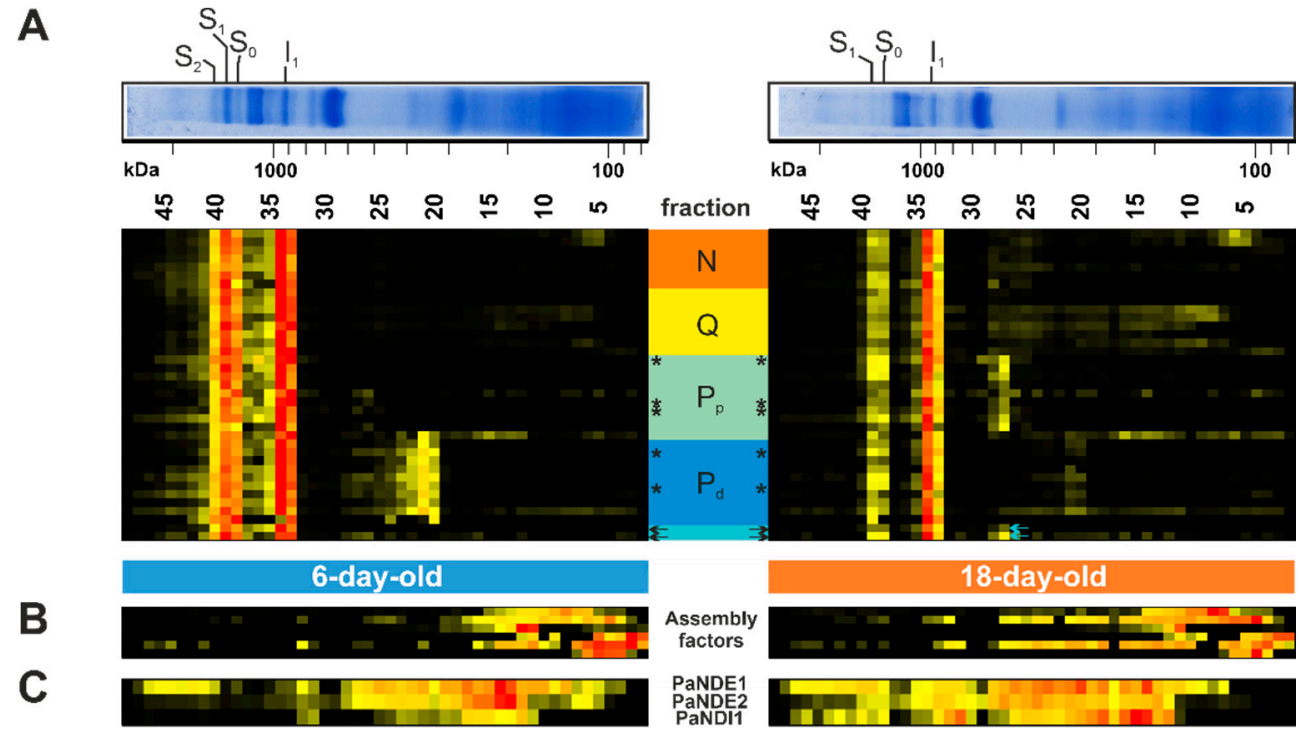

\section{D}
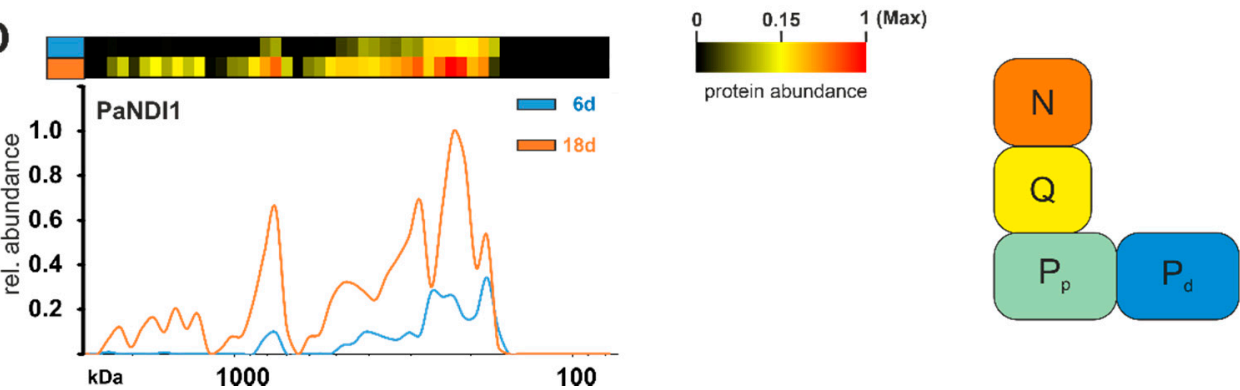

Figure 3. Increase of alternative NADH dehydrogenase PaNDI1 during aging. (A) Quantified proteins of complex I, assignment to modules, complex I assembly factors, (B) homologs of complex I assembly factors and (C) the alternative NADH dehydrogenases PaNDI1 (Pa_7_1820), PaNDE1 (Pa_1_24200) and PaNDE2 (Pa_7_5390) are represented in heat maps. Mitochondrial-encoded proteins are marked by asterisks $\left({ }^{*}\right)$. Complex I modules were assigned according to [80] N-module (N) in orange, $\mathrm{Q}$-module $(\mathrm{Q})$ in yellow, proximal proton pumping module $(\mathrm{Pp})$ in light green, distal proton pumping module $(\mathrm{Pd})$ in blue. Two unassigned subunits marked in light cyan. The color scale of heatmaps ranges from black (not identified), to yellow (15\% of the maximum), to red (maximum abundance). (D) Distribution profiles of PaNDI1 in 6-day-old (grey line) and 18-day-old (orange line) wild-type mitochondria. For detailed information about the corresponding proteins refer to Table S1D.

\subsubsection{Age-Dependent Induction of Alternative Respiration via PaAOX}

In the next set of analyses, we investigated the reduction of complex IV in more detail. Complexome profiling identified ten subunits of complex IV, whose abundance was reduced during aging (Figure 4A). Among these are the three mitochondrial-encoded catalytic subunits, PaCOX1, PaCOX2, and PaCOX3. PaCOX1 was one of the most reduced subunits in the 18-day-old sample compared to the 6-day-old sample (upper lane in Figure 4A). Since COX1 initiates the complex IV assembly [97,98], it is possible that this strong reduction affects the other subunits and leads to their reduction in quantity. Furthermore, the huge reduction of this mitochondrial-encoded subunit was expected, due to the age-related reorganization of the mtDNA and the reduction of the number of mtDNA copies [29-33]. Another explanation for the reduced PaCOX1 amount could be the fact that an intron of the PaCox1 gene codes for the plDNA, which becomes liberated during aging, leading to the mtDNA reorganization [30-32]. To reduce excessive plDNA formation, transcription of the $\mathrm{PaCoxI}$ gene might be downregulated. Indeed, a reduced $\mathrm{Pa}$ Cox1 transcript level was found in a previous transcriptome analysis [55]. Other associated 
factors such as RCF1 and complex IV assembly factors were elevated in old mitochondria, indicating stalled assembly (Figure 4B).

A
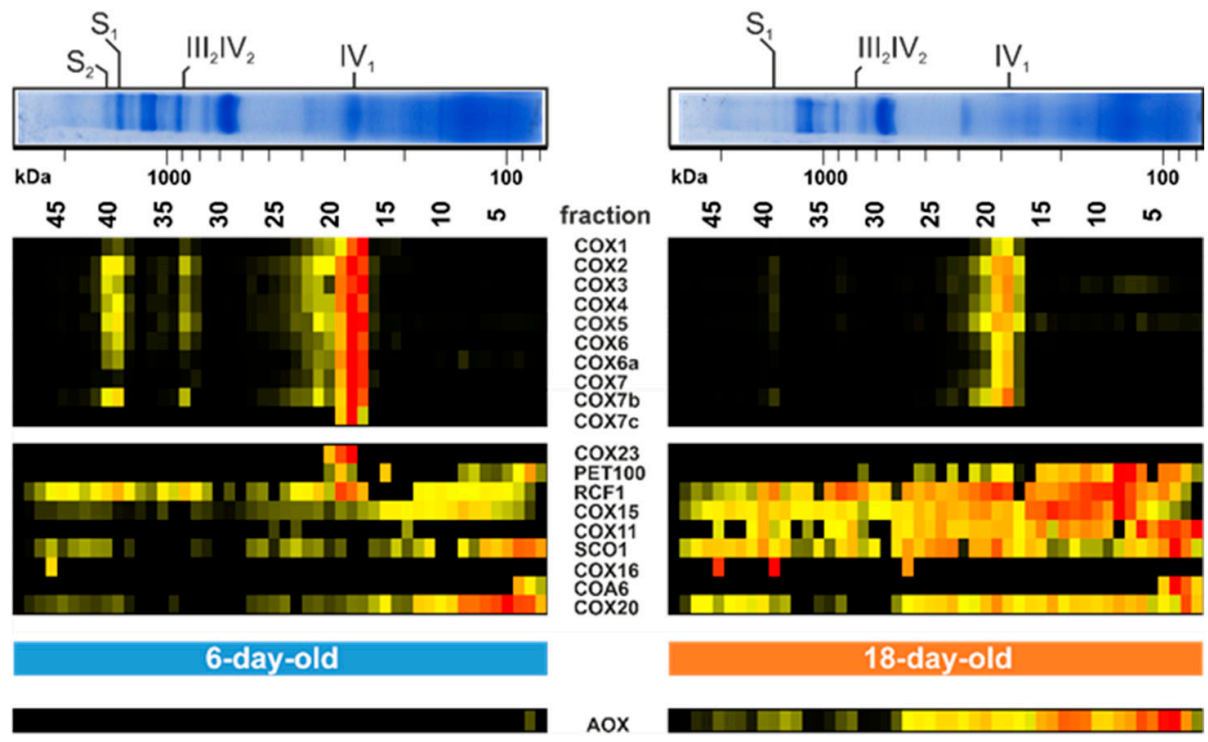

C

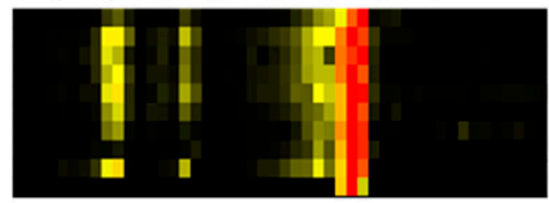

B

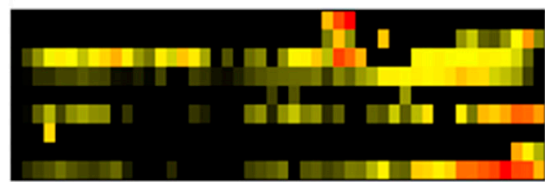

6-day-old

E
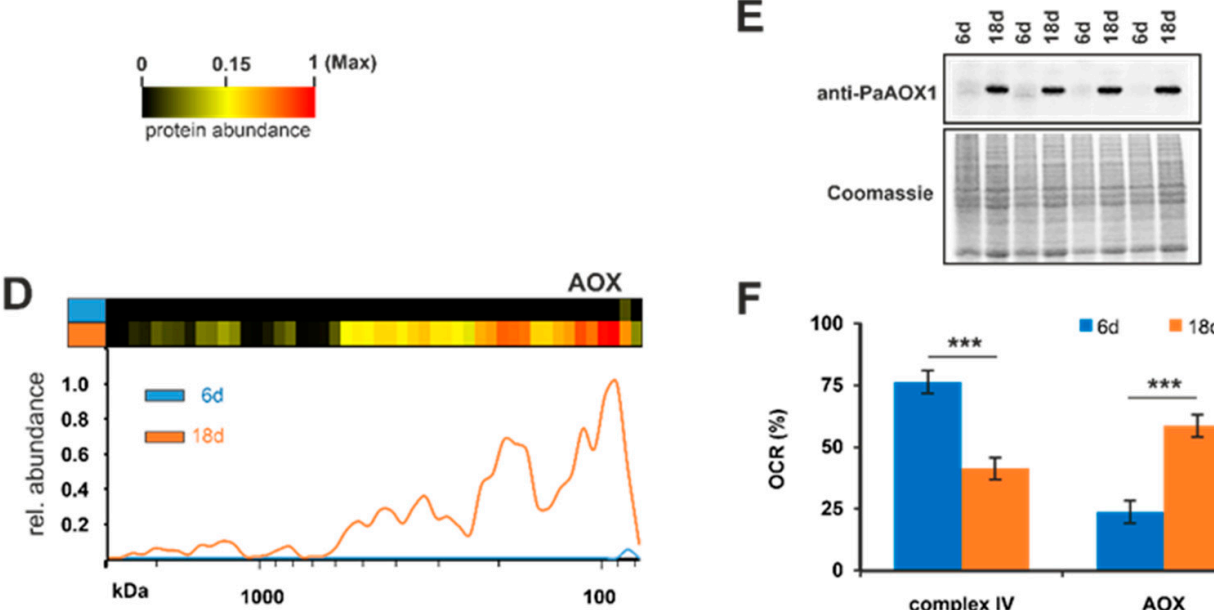

$\mathbf{F}$

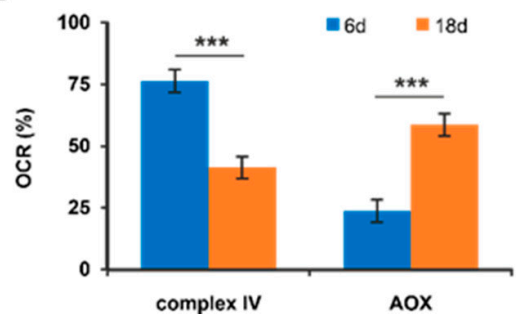

Figure 4. Age-dependent switch to AOX-dependent respiration. (A) Quantified subunits of complexes IV, (B) additional complex IV proteins and assembly factors, and (C) the alternative oxidase $(\mathrm{AOX})$ are represented in a heat map. The color scale ranges from black (not identified), to yellow (15\% of the maximum), to red (maximum abundance). (D) Complexome distribution profiles of alternative oxidase of 6-day-old and 18-day-old wild-type cultures. (E) Western blot analysis of mitochondrial protein extract of 6-day- and 18-day-old $P$. anserina wild-type cultures (each with 4 biological replicates). A specific PaAOX1 antibody was used to detect the $\sim 34 \mathrm{kDa}$ alternative oxidase (PaAOX). Coomassie staining served as loading control. (F) Relative complex IV- and AOXdependent oxygen consumption rate (OCR) of 6-day- and 18-day-old wild-type mycelium after treatment with SHAM (AOX-inhibitor) or KCN (complex IV-inhibitor).

In P. anserina, the standard complex IV-dependent respiration is known to be bypassed under certain conditions by respiration via an alternative oxidase (AOX), e.g., under the oxidative stress induced by paraquat [99]. Another example of AOX induction is the loss of complex IV, which in the absence of an alternative respiration is lethal. The $P$. anserina mutant strains grisea, $\mathrm{PaCox} 17:: b l e$, and $\mathrm{PaCox5}$ ::ble all are devoid of intact complex IV and respire via the AOX. In these mutants AOX induction leads to lifespan extension $[37,45,46,52,100,101]$. Whether the induction of the alternative respiration plays a role in the wild type of P. anserina has hardly been analyzed. An initial study analyzing 
PaAOX in the aged P. anserina wild type revealed that induction of alternative respiration does not occur during wild-type aging [100]. In contrast, a later genome-wide longitudinal transcriptome analysis revealed an increase of the PaAox transcript in middle-aged cultures, suggesting that the amount of AOX in aged cultures may also be increased [55]. Both studies used different cultivation media, leading to differences in physiological aging. Borghouts and colleagues [100] analyzed much younger cultures than Philipp and colleagues [55] and those in this study. In accordance with the transcriptome data, our current complexome dataset identified an increase of the protein amount in the 18-day-old sample compared to the 6-day-old sample (Figure 4C). We detected an increase in different fractions, with the strongest increase in fraction 3 and 4 , suggesting that $\mathrm{PaAOX}$ acts as a monomeric state $(\sim 34 \mathrm{kDa})$, but also as a dimer or an oligomer (Figure 4D). This possibility is supported by an earlier study, where two signals were detected in a western blot analysis of a 2DBN-PAGE [52]. Consistently, a dimeric form of the AOX was reported in other fungi and plants [102-104] and in oligomeric forms in mice expressing Ciona intestinalis AOX [105].

To verify the PaAOX quantity, we conducted a western blot analysis of mitochondrial extracts from both age states (Figure 4E). This analysis confirmed the increase of PaAOX in 18-day-old cultures. In 6-day-old cultures PaAOX was hardly detectable, whereas in the older cultures a huge amount was observed. To test whether this increase affects respiration, we performed oxygen consumption measurements with intact mycelia of 6-day-old and 18-day-old cultures (Figure 4F). Using the specific inhibitors potassium cyanide (KCN) for complex IV and salicylhydroxamic acid (SHAM) for AOX, we discriminated between standard respiration (complex IV-dependent) and alternative respiration (AOX-dependent). Interestingly, the higher amount of protein PaAOX detected indicates a shift of the respiration type. Consistent with earlier published data [46], young $P$. anserina wild-type cultures (6-days-old) respire predominantly $(75 \%)$ via complex IV, and only moderately (25\%) via AOX. In older cultures, this is almost turned around. We determined only $40 \%$ complex IV-dependent respiration and 60\% alternative respiration (Figure $4 \mathrm{~F}$ ). The increase of alternative respiration was not as high as the increase of the PaAOX amount. This is possibly due to the fact that alternative oxidases are post-translationally regulated. In different studies with plants, it was shown that gene expression and protein formation do not determine the AOX activity. Rather, the AOX activity is regulated via the oxidation state of cysteine residues between the monomers [106]. These results clearly demonstrate that during the aging of P. anserina wild type alternative respiration is induced. AOX-dependent respiration bypasses complex III, which is a major contributor to mitochondrial superoxide anion production [46]. In various organisms, reactive oxygen species (ROS), such as superoxide anion, have been demonstrated to induce AOX-dependent respiration [99,107-110]. We therefore assume the well-described age-dependent accumulation of ROS in P. anserina $[17,99,111]$ is responsible for AOX induction. Ultimately, this adaptive process is aimed at reducing the mitochondrial ROS load. Accordingly, in the P. anserina grisea mutant, a long-lived mutant with AOX-dependent respiration, a striking decrease in superoxide anion production was observed $[46,112,113]$.

Taken together, we show that alternative respiration via PaAOX plays a role in the aging process of the P. anserina wild type.

\subsection{Mitochondrial Translation Machinery Declines during Aging}

Beside the described age-dependent alterations further noticeable changes were detected in gel fraction $35(1 \mathrm{MDa})$ and in fractions between 40 (1.5 MDa) and 46 at $2.4 \mathrm{MDa}$ (Figure 5). The 20 corresponding proteins in fraction 35 are part of the small subunit (SSU) of the mitochondrial ribosome and the 16 clustered proteins between fractions 40 and 46 are part of the large subunit (LSU) of the mitochondrial ribosome. The SSU as well as the LSU amount decline during aging and were partly found to be disintegrated in the 18-day-old sample (Figure 5). This suggests a breakdown of the mitochondrial ribosome during aging of the P. anserina wild type. An age-associated change of the translation machinery was also found in various other organisms [114]. This decline of fully assembled mitochondrial 
ribosomes, together with the well-described decrease in mtDNA copy number [29-33], ultimately explains the dramatic decrease in the level of mitochondrial encoded proteins.
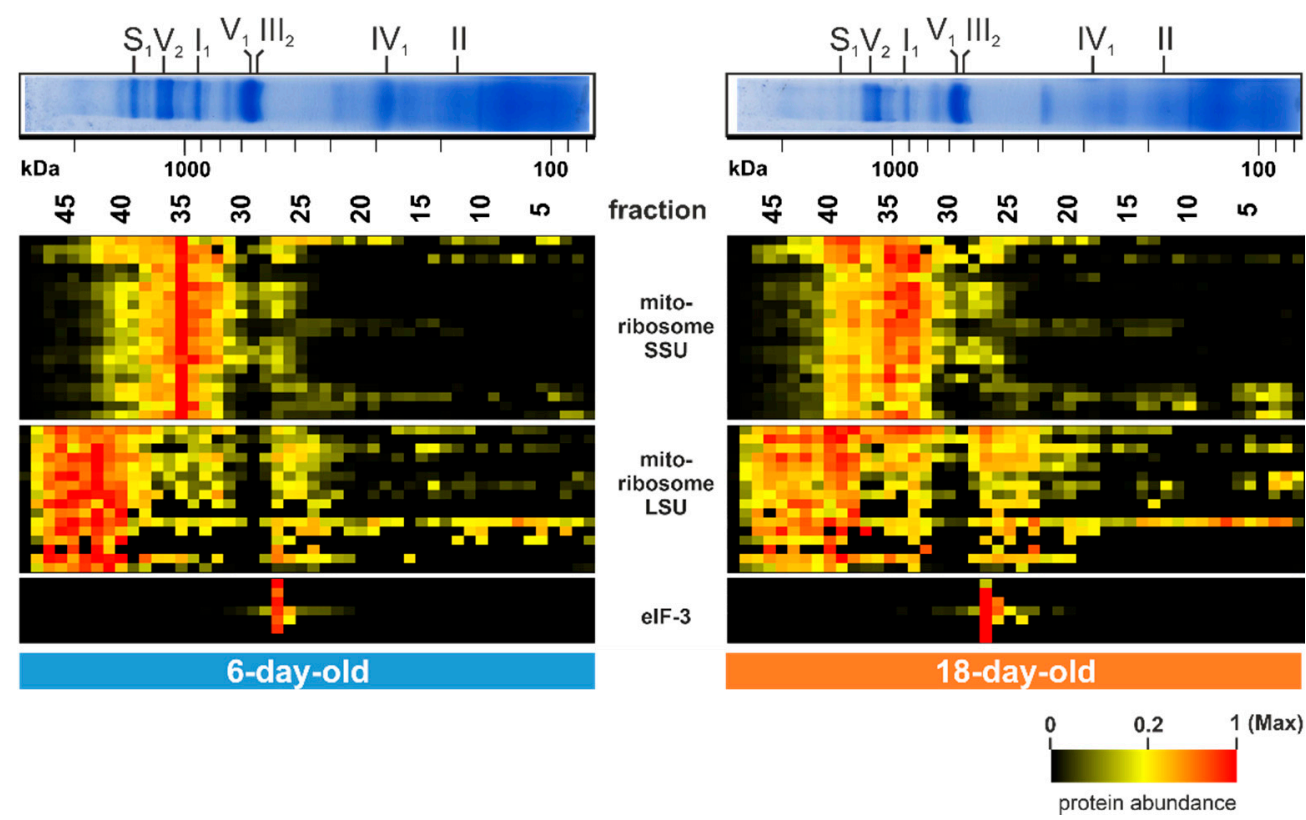

Figure 5. Translation of mitochondrial proteins alters during aging. Quantified proteins of the mitochondrial ribosome (large subunit; LSU and small subunit; SSU) and the translation initiation factor 3 (eIF-3) are represented in a heat map. The color scale ranges from black (not identified), to yellow ( $20 \%$ of the maximum), to red (maximum abundance). For detailed information about the corresponding proteins refer to Table S1E.

A further striking alteration is observed in fraction $27(550 \mathrm{kDa})$. The seven corresponding proteins were more abundant in the 18-day-old sample than in the 6-day-old sample (lower panel of Figure 5). All of these proteins are part of the translation initiation factor 3 (eIF-3). In the filamentous fungus Neurospora crassa, which is closely related to $P$. anserina, but also in humans, the eIF- 3 consists of 13 subunits, eight of them form the core structure [115-117]. The seven identified proteins are homologs of these core subunits. Age-dependent alterations of these proteins suggest an age-dependent increase of the mitochondrial association of this complex. Since, from other organism this factor is known to be part of the translation machinery of nuclear-encoded OXPHOS proteins, mitochondrial transmembrane proteins, and of the citrate cycle [118], its increased, mitochondrial association might reflect an imbalance in the co-translation of mitochondrial and nuclear-encoded OXPHOS subunits.

Overall, we identified an age-dependent alteration of components involved in mitochondrial protein translation, which may have contributed to the observed decline of complexes. We assume that this alteration leads to an imbalance between mitochondrialand nuclear-encoded proteins, inducing mitochondrial stress.

\subsection{Non-Mitochondrial Salvage Pathways Seem to Be Induced during Aging}

Hitherto, not all distinct bands of the Coomassie-stained BN-PAGE with P. anserina mitochondria were attributed to defined protein complexes. Only the bands corresponding to the OXPHOS complexes have been well characterized [52,70]. However, there are still several prominent bands, such as those above complex IV or between complex $\mathrm{V}$ and complex I, which were not assigned to specific proteins/complexes (asterisks in Figure 1B, Figure 6A). The complexome dataset allowed us to identify the corresponding complexes. Surprisingly, these proteins are not part of known mitochondrial complexes. Instead, the identified proteins are part of cytosolic protein complexes, as well as of the endoplasmic reticulum (Figure $6 \mathrm{~A}, \mathrm{~B}$ ). Proteins of the fraction $31 / 32$ are subunits of the proteasome and 
were more abundant in the older sample than in the young sample (Figure 6A; Table S1G). In yeast and mammals, the proteasome contains four rings of seven different $\alpha$ - and $\beta$ subunits, with molecular weights between 20 and $30 \mathrm{kDa}$. Altogether they form a complex with a total mass of about $700 \mathrm{kDa}$ [119]. The complex we found has a comparable size. A total of ten proteasomal proteins were detected in our study, six from the $\alpha$-subunit and four from the $\beta$-subunit (Figure 6A). The proteolytic active sites are in the inner rings of the $\beta$-subunits. Three of the seven $\beta$-subunits are proteolytic active, namely the $\beta_{1}, \beta_{2}$, and $\beta_{5}$ subunits [120]. With PaPRE3 $\left(\beta_{1}\right)$ and PaPRE2 $\left(\beta_{5}\right)$ we detected two proteolytic active subunits, which were more abundant in the 18-day-old sample than in the 6-day-old sample (hashtag in Figure 6A).

A

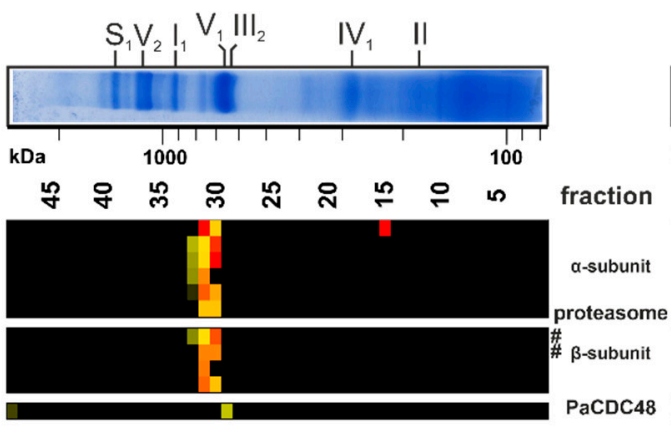

B

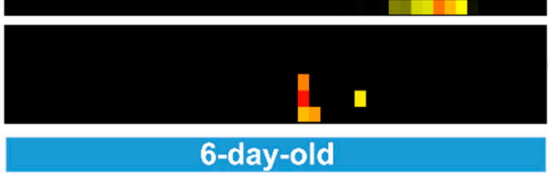

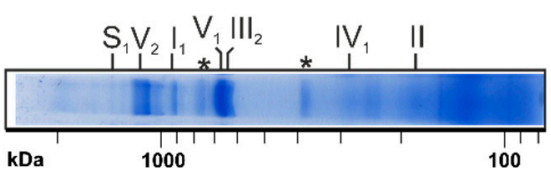

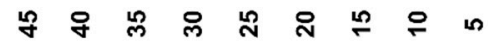
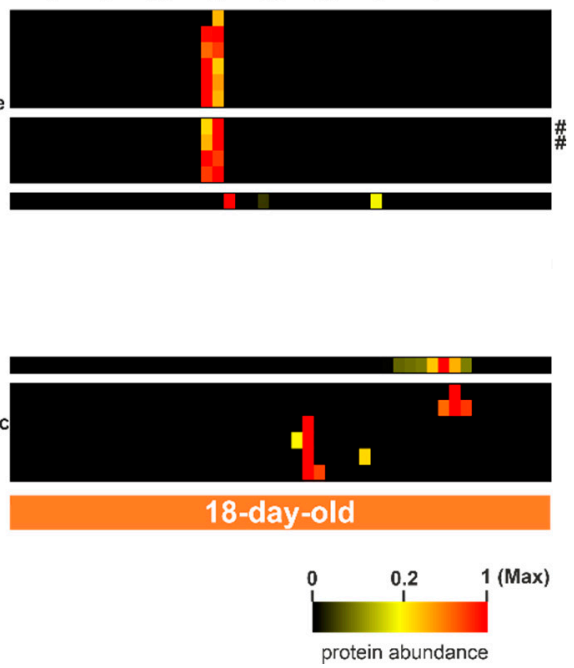

Figure 6. Age-dependent increase of non-mitochondrial complexes. (A) Quantified proteins of the proteasome and PaCDC48 (Pa_7_5590) are represented in a heat map. (B) Selected quantified proteins of the endoplasmic reticulum and PaMDM10 (Pa_7_11600) are represented in a heat map. The color scale ranges from black (not identified), to yellow ( $20 \%$ of the maximum), to red (maximum abundance). Asterisks ${ }^{*}$ ) mark hitherto uncharacterized protein bands. Hashtags (\#) mark two catalytic subunits (PaPRE3 and PaPRE2) of the proteasome $\beta$-subunits. For detailed information about the corresponding proteins refer to Table S1F.

The increased abundance of the proteasomal proteins suggests an increased recruitment of the proteasome to the mitochondria in the aged P. anserina wild type. The proteasome is an important component of the protein quality control machinery [121-123]. It does not only degrade cytosolic proteins, but also proteins of other cellular compartments/organelles. The degradation of damaged mitochondrial proteins via the proteasome is called 'mitochondria-associated degradation' (MAD) and was first discovered in S. cerevisiae [124]. The data presented here are the first indication of an enhanced degradation of damaged mitochondrial proteins via MAD during the aging process of $P$. anserina. A further hint at such an age-dependent MAD increase is the detection of PaCDC48, which was found in a higher amount in the older (18-day-old) compared to the young (6-day-old) sample (lower panel of Figure 6A). PaCDC48 is a homolog of the AAA-ATPase CDC48 of $S$. cerevisiae $[124,125]$. It is part of a protein complex binding damaged proteins and translocating them for degradation to the proteasome [126]. The increased association of the proteasome with mitochondria fits the accumulation eIF-3 in the mitochondrial fraction of aged mitochondria. To allow the formation of fully assembled OXPHOS complexes, the 
translation and importing of nuclear-encoded subunits needs to be well coordinated with the translation of mitochondria-encoded subunits. An imbalance of individual proteins due to reduced generation of mitochondria-encoded subunits may result in an import block of nuclear-encoded proteins. The accumulation of these proteins at the mitochondrial surface might attract the proteasome and lead to PaCDC48 recruitment as a salvage pathway.

Another possible non-mitochondrial salvage pathway may be the attachment of the ER to the mitochondrion. Indeed, we found four ER proteins in fraction 22 as part of the other prominent uncharacterized BN-PAGE band (Figure 6B; Table S1). Additional two ER-linked proteins were detected in fraction 9. All of these proteins are ER membrane proteins, suggesting that the presence of these proteins is indicative of mitochondria-ER membrane contacts. The level of these proteins increases during aging (Figure 6B) and, therefore, we suggest an increase in mitochondria-ER connections during aging. Mitochondria and the ER are linked via the ERMES (ER-mitochondria encounter structure) complex [127]. A central protein of this connecting complex is MDM10, a mitochondrial outer membrane protein [128]. In our analysis we observed an age-dependent co-migration of PaMDM10 together with ER membrane proteins in a 150 kDa complex in fraction 10 (upper panel of Figure 6B). Intimate connections between ER and mitochondria membranes facilitate the exchange of ions, proteins, and lipids, thereby positively affecting mitochondrial function [129-131]. For instance, it has been demonstrated that mitochondria and ER cooperate, with the help of the proteasome, in the quality control of tail-anchored proteins [132]. Moreover, ER safeguards the import of mitochondrial proteins [132,133]. An age-dependent increase of ER-mitochondria association has also been observed in porcine aortic endothelial cells [134], suggesting that ER recruitment represents an evolutionary conserved salvage pathway. Beside the role of the ER and mitochondria in salvage pathways, these contacts may be linked to increased mitochondrial fission, as was shown to occur during the aging of P. anserina [17]. Such a role has been demonstrated in human cell lines, where the ER-mitochondria contact sites define the position at which the fission machinery assembles at the mitochondria before fission [135-137].

\section{Conclusions}

Overall, during the aging of P. anserina, pronounced changes in the mitochondrial complexome profile occur. The fundamental age-dependent reorganization of the respiratory chain via the induction of AOX, together with the decline in the amount of mtRSC, clearly affect the ability of the mitochondria to generate ATP. Moreover, the loss of mitochondrial ribosome subunits impairs mitochondrial translation; thereby, further compromising mitochondrial function. Interestingly and hitherto unknown, in P. anserina these alterations appear to induce the recruitment of components of compensatory pathways, such as the proteasome and the ER to mitochondria, to counteract these impairments. Future studies need to address the regulation of these salvage pathways in more detail, to provide a better understanding of their role in the prevention of age-dependent impairments.

Supplementary Materials: The following are available online at https:/ / www.mdpi.com/article/10 .3390/cells10123319/s1, Table S1: Total complexome heat map.

Author Contributions: Conceptualization, H.D.O. and V.W.; validation, V.W., I.W. and H.D.O.; investigation, V.W., J.M. and I.W.; resources, H.D.O. and I.W.; writing-original draft preparation, V.W. and H.D.O.; writing-review and editing, H.D.O., I.W., J.M. and V.W.; visualization, V.W.; supervision, H.D.O. All authors have read and agreed to the published version of the manuscript.

Funding: This work was funded by the Deutsche Forschungsgemeinschaft (DFG, German Research Foundation) Os75/17-2 to H.D.O. and Wi3728/1-1 to I.W.

Institutional Review Board Statement: Not applicable.

Informed Consent Statement: Not applicable. 
Data Availability Statement: The complexome profiling data are available in ProteomeXchange (http:/ / www.proteomexchange.org/) via the PRIDE [138] partner repository with the identifiers PXD029352.

Acknowledgments: We thank Andrea Hamann for discussion of the work and input in the final preparation of the manuscript.

Conflicts of Interest: The authors declare no conflict of interest.

\section{References}

1. Kirkwood, T.B. Understanding the odd science of aging. Cell 2005, 120, 437-447. [CrossRef]

2. Kirkwood, T.B.; Austad, S.N. Why do we age? Nature 2000, 408, 233-238. [CrossRef] [PubMed]

3. Vijg, J.; Campisi, J. Puzzles, promises and a cure for ageing. Nature 2008, 454, 1065-1071. [CrossRef] [PubMed]

4. Breitenbach, M.; Laun, P.; Dickinson, J.R.; Klocker, A.; Rinnerthaler, M.; Dawes, I.W.; Aung-Htut, M.T.; Breitenbach-Koller, L.; Caballero, A.; Nyström, T.; et al. The role of mitochondria in the aging processes of yeast. Subcell. Biochem. 2012, 57, 55-78. [CrossRef] [PubMed]

5. Harman, D. The biologic clock: The mitochondria? J. Am. Geriatr. Soc. 1972, 20, 145-147. [CrossRef]

6. Jazwinski, S.M.; Kriete, A. The yeast retrograde response as a model of intracellular signaling of mitochondrial dysfunction. Front. Physiol. 2012, 3, 139. [CrossRef]

7. Linnane, A.W.; Marzuki, S.; Ozawa, T.; Tanaka, M. Mitochondrial DNA mutations as an important contributor to ageing and degenerative diseases. Lancet 1989, 1, 642-645. [CrossRef]

8. Osiewacz, H.D. Mitochondrial functions and aging. Gene 2002, 286, 65-71. [CrossRef]

9. Osiewacz, H.D. Role of mitochondria in aging and age-related disease. Exp. Gerontol. 2010, 45, 465. [CrossRef]

10. Fischer, F.; Hamann, A.; Osiewacz, H.D. Mitochondrial quality control: An integrated network of pathways. Trends Biochem. Sci. 2012, 37, 284-292. [CrossRef]

11. Tatsuta, T.; Langer, T. Quality control of mitochondria: Protection against neurodegeneration and ageing. EMBO J. 2008, 27, 306-314. [CrossRef] [PubMed]

12. Marcou, D. Notion de longévité et nature cytoplasmatique du déterminant de sénescence chez quelques champignons. Ann. Sci. Biol. Bot. Veg. 1961, 12, 653-764.

13. Tudzynski, P.; Esser, K. Inhibitors of mitochondrial function prevent senescence in the ascomycete Podospora anserina. Mol. Gen. Genet. 1977, 153, 111-113. [CrossRef] [PubMed]

14. Osiewacz, H.D.; Schürmanns, L. A network of pathways controlling cellular homeostasis affects the onset of senescence in Podospora anserina. J. Fungi 2021, 7, 263. [CrossRef]

15. Esser, K.; Tudzynski, P. Senescence in Fungi; CRC Press: Boca Raton, FL, USA, 1980; pp. 67-83.

16. Osiewacz, H.D. Aging in fungi: Role of mitochondria in Podospora anserina. Mech. Ageing Dev. 2002, 123, 755-764. [CrossRef]

17. Scheckhuber, C.Q.; Erjavec, N.; Tinazli, A.; Hamann, A.; Nyström, T.; Osiewacz, H.D. Reducing mitochondrial fission results in increased life span and fitness of two fungal ageing models. Nat. Cell Biol. 2007, 9, 99-105. [CrossRef]

18. Brust, D.; Daum, B.; Breunig, C.; Hamann, A.; Kühlbrandt, W.; Osiewacz, H.D. Cyclophilin D links programmed cell death and organismal aging in Podospora anserina. Aging Cell 2010, 9, 761-775. [CrossRef] [PubMed]

19. Daum, B.; Walter, A.; Horst, A.; Osiewacz, H.D.; Kühlbrandt, W. Age-dependent dissociation of ATP synthase dimers and loss of inner-membrane cristae in mitochondria. Proc. Natl. Acad. Sci. USA 2013, 110, 15301-15306. [CrossRef]

20. Davies, K.M.; Strauss, M.; Daum, B.; Kief, J.H.; Osiewacz, H.D.; Rycovska, A.; Zickermann, V.; Kuhlbrandt, W. Macromolecular organization of ATP synthase and complex I in whole mitochondria. Proc. Natl. Acad. Sci. USA 2011, 108, 14121-14126. [CrossRef]

21. Rampello, N.G.; Stenger, M.; Westermann, B.; Osiewacz, H.D. Impact of $F_{1} F_{0}$-ATP-synthase dimer assembly factors on mitochondrial function and organismic aging. Microb. Cell 2018, 5, 198-207. [CrossRef]

22. Warnsmann, V.; Marschall, L.-M.; Osiewacz, H.D. Impaired $\mathrm{F}_{1} \mathrm{~F}_{\mathrm{o}}$-ATP-synthase dimerization leads to the induction of cyclophilin D-mediated autophagy-dependent cell death and accelerated aging. Cells 2021, 10, 757. [CrossRef] [PubMed]

23. Beregi, E.; Regius, O.; Huttl, T.; Gobl, Z. Age-related changes in the skeletal muscle cells. Z. Gerontol. 1988, $21,83-86$.

24. Brandt, T.; Mourier, A.; Tain, L.S.; Partridge, L.; Larsson, N.G.; Kühlbrandt, W. Changes of mitochondrial ultrastructure and function during ageing in mice and Drosophila. Elife 2017, 6, e24662. [CrossRef] [PubMed]

25. Crane, J.D.; Devries, M.C.; Safdar, A.; Hamadeh, M.J.; Tarnopolsky, M.A. The effect of aging on human skeletal muscle mitochondrial and intramyocellular lipid ultrastructure. J. Gerontol. A Biol. Sci. Med. Sci. 2010, 65, 119-128. [CrossRef]

26. McQuibban, G.A.; Lee, J.R.; Zheng, L.; Juusola, M.; Freeman, M. Normal mitochondrial dynamics requires rhomboid-7 and affects Drosophila lifespan and neuronal function. Curr. Biol. 2006, 16, 982-989. [CrossRef] [PubMed]

27. Young, L.C.; Bone, K.M.; Wang, P.; Wu, F.; Adam, B.A.; Hegazy, S.; Gelebart, P.; Holovati, J.; Li, L.; Andrew, S.E.; et al. Fusion tyrosine kinase NPM-ALK deregulates MSH2 and suppresses DNA mismatch repair function novel insights into a potent oncoprotein. Am. J. Pathol. 2011, 179, 411-421. [CrossRef]

28. Zhao, L.; Zou, X.; Feng, Z.; Luo, C.; Liu, J.; Li, H.; Chang, L.; Wang, H.; Li, Y.; Long, J.; et al. Evidence for association of mitochondrial metabolism alteration with lipid accumulation in aging rats. Exp. Gerontol. 2014, 56, 3-12. [CrossRef] [PubMed] 
29. Cummings, D.J.; Belcour, L.; Grandchamp, C. Mitochondrial DNA from Podospora anserina. II. Properties of mutant DNA and multimeric circular DNA from senescent cultures. Mol. Gen. Genet. 1979, 171, 239-250. [CrossRef]

30. Osiewacz, H.D.; Esser, K. The mitochondrial plasmid of Podospora anserina: A mobile intron of a mitochondrial gene. Curr. Genet. 1984, 8, 299-305. [CrossRef]

31. Stahl, U.; Lemke, P.A.; Tudzynski, P.; Kück, U.; Esser, K. Evidence for plasmid like DNA in a filamentous fungus, the ascomycete Podospora anserina. Mol. Gen. Genet. 1978, 162, 341-343. [CrossRef]

32. Kück, U.; Osiewacz, H.D.; Schmidt, U.; Kappelhoff, B.; Schulte, E.; Stahl, U.; Esser, K. The onset of senescence is affected by DNA rearrangements of a discontinuous mitochondrial gene in Podospora anserina. Curr. Genet. 1985, 9, 373-382. [CrossRef] [PubMed]

33. Kück, U.; Stahl, U.; Esser, K. Plasmid-like DNA is part of mitochondrial DNA in Podospora anserina. Curr. Genet. 1981, 3, 151-156. [CrossRef] [PubMed]

34. Hermanns, J.; Asseburg, A.; Osiewacz, H.D. Evidence for a life span-prolonging effect of a linear plasmid in a longevity mutant of Podospora anserina. Mol. Gen. Genet. 1994, 243, 297-307. [CrossRef] [PubMed]

35. Osiewacz, H.D.; Nuber, U. GRISEA, a putative copper-activated transcription factor from Podospora anserina involved in differentiation and senescence. Mol. Gen. Genet. 1996, 252, 115-124. [CrossRef]

36. Schulte, E.; Kück, U.; Esser, K. Extrachromosomal mutants from Podospora anserina: Permanent vegetative growth in spite of multiple recombination events in the mitochondrial genome. Mal. Gen. Genet. 1988, 211, 342-349. [CrossRef]

37. Stumpferl, S.W.; Stephan, O.; Osiewacz, H.D. Impact of a disruption of a pathway delivering copper to mitochondria on Podospora anserina metabolism and life span. Eukaryot. Cell 2004, 3, 200-211. [CrossRef] [PubMed]

38. Cortopassi, G.A.; Arnheim, N. Detection of a specific mitochondrial DNA deletion in tissues of older humans. Nucleic Acids Res. 1990, 18, 6927-6933. [CrossRef]

39. Melov, S.; Hertz, G.Z.; Stormo, G.D.; Johnson, T.E. Detection of deletions in the mitochondrial genome of Caenorhabditis elegans. Nucleic Acids Res. 1994, 22, 1075-1078. [CrossRef]

40. Wallace, D.C. Mitochondrial genetics: A paradigm for aging and degenerative diseases? Science 1992, 256, 628-632. [CrossRef]

41. Kumaran, S.; Panneerselvam, K.S.; Shila, S.; Sivarajan, K.; Panneerselvam, C. Age-associated deficit of mitochondrial oxidative phosphorylation in skeletal muscle: Role of carnitine and lipoic acid. Mol. Cell Biochem. 2005, 280, 83-89. [CrossRef]

42. Lenaz, G. Role of mitochondria in oxidative stress and ageing. Biochim. Biophys. Acta 1998, 1366, 53-67. [CrossRef]

43. Ojaimi, J.; Masters, C.L.; Opeskin, K.; McKelvie, P.; Byrne, E. Mitochondrial respiratory chain activity in the human brain as a function of age. Mech. Ageing Dev. 1999, 111, 39-47. [CrossRef]

44. Yen, T.C.; Chen, Y.S.; King, K.L.; Yeh, S.H.; Wei, Y.H. Liver mitochondrial respiratory functions decline with age. Biochem. Biophys. Res. Commun. 1989, 165, 944-1003. [CrossRef]

45. Dufour, E.; Boulay, J.; Rincheval, V.; Sainsard-Chanet, A. A causal link between respiration and senescence in Podospora anserina. Proc. Natl. Acad. Sci. USA 2000, 97, 4138-4143. [CrossRef]

46. Gredilla, R.; Grief, J.; Osiewacz, H.D. Mitochondrial free radical generation and lifespan control in the fungal aging model Podospora anserina. Exp. Gerontol. 2006, 41, 439-447. [CrossRef]

47. Coskun, P.; Wyrembak, J.; Schriner, S.E.; Chen, H.W.; Marciniack, C.; Laferla, F.; Wallace, D.C. A mitochondrial etiology of Alzheimer and Parkinson disease. Biochim. Biophys. Acta 2012, 1820, 553-564. [CrossRef]

48. Wallace, D.C. A mitochondrial paradigm of metabolic and degenerative diseases, aging, and cancer: A dawn for evolutionary medicine. Annu. Rev. Genet. 2005, 39, 359-407. [CrossRef]

49. Schägger, H.; Pfeiffer, K. Supercomplexes in the respiratory chains of yeast and mammalian mitochondria. EMBO J. 2000, 19, 1777-1783. [CrossRef]

50. Acin-Perez, R.; Fernandez-Silva, P.; Peleato, M.L.; Perez-Martos, A.; Enriquez, J.A. Respiratory active mitochondrial supercomplexes. Mol. Cell 2008, 32, 529-539. [CrossRef]

51. Bianchi, C.; Genova, M.L.; Parenti Castelli, G.; Lenaz, G. The mitochondrial respiratory chain is partially organized in a supercomplex assembly: Kinetic evidence using flux control analysis. J. Biol. Chem. 2004, 279, 36562-36569. [CrossRef]

52. Krause, F.; Scheckhuber, C.Q.; Werner, A.; Rexroth, S.; Reifschneider, N.H.; Dencher, N.A.; Osiewacz, H.D. Supramolecular organization of cytochrome c oxidase- and alternative oxidase-dependent respiratory chains in the filamentous fungus Podospora anserina. J. Biol. Chem. 2004, 279, 26453-26461. [CrossRef]

53. Fischer, F.; Filippis, C.; Osiewacz, H.D. RCF1-dependent respiratory supercomplexes are integral for lifespan-maintenance in a fungal ageing model. Sci. Rep. 2015, 5, 12697. [CrossRef]

54. Weil, A.; Luce, K.; Dröse, S.; Wittig, I.; Brandt, U.; Osiewacz, H.D. Unmasking a temperature-dependent effect of the P. anserina i-AAA protease on aging and development. Cell Cycle 2011, 10, 4280-4290. [CrossRef] [PubMed]

55. Philipp, O.; Hamann, A.; Servos, J.; Werner, A.; Koch, I.; Osiewacz, H.D. A genome-wide longitudinal transcriptome analysis of the aging model Podospora anserina. PLoS One 2013, 8, e83109. [CrossRef]

56. Chimi, M.A.; Drose, S.; Wittig, I.; Heide, H.; Steger, M.; Werner, A.; Hamann, A.; Osiewacz, H.D.; Brandt, U. Age-related changes in the mitochondrial proteome of the fungus Podospora anserina analyzed by 2D-DIGE and LC-MS/MS. J. Proteomics 2013, 91, 358-374. [CrossRef] [PubMed]

57. Groebe, K.; Krause, F.; Kunstmann, B.; Unterluggauer, H.; Reifschneider, N.H.; Scheckhuber, C.Q.; Sastri, C.; Stegmann, W.; Wozny, W.; Schwall, G.P.; et al. Differential proteomic profiling of mitochondria from Podospora anserina, rat and human reveals distinct patterns of age-related oxidative changes. Exp. Gerontol. 2007, 42, 887-898. [CrossRef] [PubMed] 
58. Ramallo Guevara, C.; Philipp, O.; Hamann, A.; Werner, A.; Osiewacz, H.D.; Rexroth, S.; Rogner, M.; Poetsch, A. Global protein oxidation profiling suggests efficient mitochondrial proteome homeostasis during aging. Mol. Cell Proteomics 2016, 15, 1692-1709. [CrossRef]

59. Plohnke, N.; Hamann, A.; Poetsch, A.; Osiewacz, H.D.; Rogner, M.; Rexroth, S. Proteomic analysis of mitochondria from senescent Podospora anserina casts new light on ROS dependent aging mechanisms. Exp. Gerontol. 2014, 56, 13-25. [CrossRef]

60. Heide, H.; Bleier, L.; Steger, M.; Ackermann, J.; Drose, S.; Schwamb, B.; Zornig, M.; Reichert, A.S.; Koch, I.; Wittig, I.; et al. Complexome profiling identifies TMEM126B as a component of the mitochondrial complex I assembly complex. Cell Metab. 2012, 16, 538-549. [CrossRef]

61. Giese, H.; Meisterknecht, J.; Heidler, J.; Wittig, I. Mitochondrial complexome profiling. Methods Mol. Biol. 2021, $2192,269-285$. [CrossRef]

62. Wessels, H.J.; Vogel, R.O.; van den Heuvel, L.; Smeitink, J.A.; Rodenburg, R.J.; Nijtmans, L.G.; Farhoud, M.H. LC-MS/MS as an alternative for SDS-PAGE in blue native analysis of protein complexes. Proteomics 2009, 9, 4221-4228. [CrossRef]

63. Wittig, I.; Malacarne, P.F. Complexome profiling: Assembly and remodeling of protein complexes. Int. J. Mol. Sci. 2021, 22, 7809. [CrossRef]

64. Rizet, G. Sur l'impossibilité d'obtenir la multiplication végétative ininterrompue et illimitée de l'ascomycète Podospora anserina. C. R. Hebd. Seances Acad. Sci. 1953, 237, 838-840. [PubMed]

65. Osiewacz, H.D.; Hamann, A.; Zintel, S. Assessing organismal aging in the filamentous fungus Podospora anserina. Methods Mol. Biol. 2013, 965, 439-462. [CrossRef] [PubMed]

66. Schägger, H. Blue-native gels to isolate protein complexes from mitochondria. Methods Cell Biol. 2001, 65, 231-244. [CrossRef] [PubMed]

67. Wittig, I.; Braun, H.P.; Schägger, H. Blue native PAGE. Nat. Protoc. 2006, 1, 418-428. [CrossRef]

68. Cox, J.; Mann, M. MaxQuant enables high peptide identification rates, individualized p.p.b.-range mass accuracies and proteomewide protein quantification. Nat. Biotechnol. 2008, 26, 1367-1372. [CrossRef] [PubMed]

69. Giese, H.; Ackermann, J.; Heide, H.; Bleier, L.; Drose, S.; Wittig, I.; Brandt, U.; Koch, I. NOVA: A software to analyze complexome profiling data. Bioinformatics 2015, 31, 440-441. [CrossRef]

70. Krause, F.; Scheckhuber, C.Q.; Werner, A.; Rexroth, S.; Reifschneider, N.H.; Dencher, N.A.; Osiewacz, H.D. OXPHOS Supercomplexes: Respiration and life-span control in the aging model Podospora anserina. Ann. N. Y. Acad. Sci. 2006, 1067, 106-115. [CrossRef]

71. Frenzel, M.; Rommelspacher, H.; Sugawa, M.D.; Dencher, N.A. Ageing alters the supramolecular architecture of OxPhos complexes in rat brain cortex. Exp. Gerontol. 2010, 45, 563-572. [CrossRef]

72. Gomez, L.A.; Monette, J.S.; Chavez, J.D.; Maier, C.S.; Hagen, T.M. Supercomplexes of the mitochondrial electron transport chain decline in the aging rat heart. Arch. Biochem. Biophys. 2009, 490, 30-35. [CrossRef] [PubMed]

73. Benzi, G.; Pastoris, O.; Marzatico, F.; Villa, R.F.; Dagani, F.; Curti, D. The mitochondrial electron transfer alteration as a factor involved in the brain aging. Neurobiol. Aging 1992, 13, 361-368. [CrossRef]

74. Lenaz, G.; Bovina, C.; Castelluccio, C.; Fato, R.; Formiggini, G.; Genova, M.L.; Marchetti, M.; Pich, M.M.; Pallotti, F.; Parenti Castelli, G.; et al. Mitochondrial complex I defects in aging. Mol. Cell Biochem. 1997, 174, 329-333. [CrossRef]

75. Manczak, M.; Jung, Y.; Park, B.S.; Partovi, D.; Reddy, P.H. Time-course of mitochondrial gene expressions in mice brains: Implications for mitochondrial dysfunction, oxidative damage, and cytochrome c in aging. J. Neurochem. 2005, 92, 494-504. [CrossRef]

76. McKenzie, M.; Lazarou, M.; Thorburn, D.R.; Ryan, M.T. Mitochondrial respiratory chain supercomplexes are destabilized in Barth Syndrome patients. J. Mol. Biol. 2006, 361, 462-469. [CrossRef]

77. Schapira, A.H.; Cooper, J.M.; Dexter, D.; Clark, J.B.; Jenner, P.; Marsden, C.D. Mitochondrial complex I deficiency in Parkinson's disease. J. Neurochem. 1990, 54, 823-827. [CrossRef] [PubMed]

78. Rosca, M.G.; Vazquez, E.J.; Kerner, J.; Parland, W.; Chandler, M.P.; Stanley, W.; Sabbah, H.N.; Hoppel, C.L. Cardiac mitochondria in heart failure: Decrease in respirasomes and oxidative phosphorylation. Cardiovasc. Res. 2008, 80, 30-39. [CrossRef] [PubMed]

79. Scolletta, S.; Biagioli, B. Energetic myocardial metabolism and oxidative stress: Let's make them our friends in the fight against heart failure. Biomed. Pharmacother. 2010, 64, 203-207. [CrossRef] [PubMed]

80. Zickermann, V.; Kerscher, S.; Zwicker, K.; Tocilescu, M.A.; Radermacher, M.; Brandt, U. Architecture of complex I and its implications for electron transfer and proton pumping. Biochim. Biophys. Acta 2009, 1787, 574-583. [CrossRef]

81. Guerrero-Castillo, S.; Baertling, F.; Kownatzki, D.; Wessels, H.J.; Arnold, S.; Brandt, U.; Nijtmans, L. The assembly pathway of mitochondrial respiratory chain complex I. Cell Metab. 2017, 25, 128-139. [CrossRef]

82. Brandt, U. Energy converting NADH:quinone oxidoreductase (complex I). Annu. Rev. Biochem. 2006, 75, 69-92. [CrossRef]

83. Andrews, B.; Carroll, J.; Ding, S.; Fearnley, I.M.; Walker, J.E. Assembly factors for the membrane arm of human complex I. Proc. Natl. Acad. Sci. USA 2013, 110, 18934-18939. [CrossRef]

84. Senkler, J.; Senkler, M.; Eubel, H.; Hildebrandt, T.; Lengwenus, C.; Schertl, P.; Schwarzlander, M.; Wagner, S.; Wittig, I.; Braun, H.P. The mitochondrial complexome of Arabidopsis thaliana. Plant J. 2017, 89, 1079-1092. [CrossRef] [PubMed]

85. Wirth, C.; Brandt, U.; Hunte, C.; Zickermann, V. Structure and function of mitochondrial complex I. Biochim. Biophys. Acta 2016, 1857, 902-914. [CrossRef] [PubMed] 
86. Stenton, S.L.; Sheremet, N.L.; Catarino, C.B.; Andreeva, N.A.; Assouline, Z.; Barboni, P.; Barel, O.; Berutti, R.; Bychkov, I.; Caporali, L.; et al. Impaired complex I repair causes recessive Leber's hereditary optic neuropathy. J. Clin. Investig. 2021, 131. [CrossRef]

87. Szczepanowska, K.; Senft, K.; Heidler, J.; Herholz, M.; Kukat, A.; Höhne, M.N.; Hofsetz, E.; Becker, C.; Kaspar, S.; Giese, H.; et al. A salvage pathway maintains highly functional respiratory complex I. Nat. Commun. 2020, 11, 1643. [CrossRef] [PubMed]

88. Kerscher, S.J. Diversity and origin of alternative NADH:ubiquinone oxidoreductases. Biochim. Biophys. Acta 2000, 1459, $274-283$. [CrossRef]

89. De Vries, S.; Van Witzenburg, R.; Grivell, L.A.; Marres, C.A. Primary structure and import pathway of the rotenone-insensitive NADH-ubiquinone oxidoreductase of mitochondria from Saccharomyces cerevisiae. Eur. J. Biochem. 1992, 203, 587-592. [CrossRef]

90. Overkamp, K.M.; Bakker, B.M.; Kotter, P.; van Tuijl, A.; de Vries, S.; van Dijken, J.P.; Pronk, J.T. In vivo analysis of the mechanisms for oxidation of cytosolic NADH by Saccharomyces cerevisiae mitochondria. J. Bacteriol. 2000, 182, 2823-2830. [CrossRef]

91. Maas, M.F.; Sellem, C.H.; Krause, F.; Dencher, N.A.; Sainsard-Chanet, A. Molecular gene therapy: Overexpression of the alternative NADH dehydrogenase NDI1 restores overall physiology in a fungal model of respiratory complex I deficiency. J. Mol. Biol. 2010, 399, 31-40. [CrossRef] [PubMed]

92. Bai, Y.; Hajek, P.; Chomyn, A.; Chan, E.; Seo, B.B.; Matsuno-Yagi, A.; Yagi, T.; Attardi, G. Lack of complex I activity in human cells carrying a mutation in MtDNA-encoded ND4 subunit is corrected by the Saccharomyces cerevisiae NADH-quinone oxidoreductase (NDI1) gene. J. Biol. Chem. 2001, 276, 38808-38813. [CrossRef]

93. DeCorby, A.; Gaskova, D.; Sayles, L.C.; Lemire, B.D. Expression of Ndi1p, an alternative NADH:ubiquinone oxidoreductase, increases mitochondrial membrane potential in a C. elegans model of mitochondrial disease. Biochim. Biophys. Acta 2007, 1767, 1157-1163. [CrossRef] [PubMed]

94. Park, J.S.; Li, Y.F.; Bai, Y. Yeast NDI1 improves oxidative phosphorylation capacity and increases protection against oxidative stress and cell death in cells carrying a Leber's hereditary optic neuropathy mutation. Biochim. Biophys. Acta 2007, 1772, 533-542. [CrossRef] [PubMed]

95. Seo, B.B.; Nakamaru-Ogiso, E.; Flotte, T.R.; Matsuno-Yagi, A.; Yagi, T. In vivo complementation of complex I by the yeast Ndi1 enzyme. Possible application for treatment of Parkinson disease. J. Biol. Chem. 2006, 281, 14250-14255. [CrossRef] [PubMed]

96. Seo, B.B.; Wang, J.; Flotte, T.R.; Yagi, T.; Matsuno-Yagi, A. Use of the NADH-quinone oxidoreductase (NDI1) gene of Saccharomyces cerevisiae as a possible cure for complex I defects in human cells. J. Biol. Chem. 2000, 275, 37774-37778. [CrossRef]

97. Nijtmans, L.G.; Taanman, J.W.; Muijsers, A.O.; Speijer, D.; Van den Bogert, C. Assembly of cytochrome-c oxidase in cultured human cells. Eur. J. Biochem. 1998, 254, 389-394. [CrossRef]

98. Signes, A.; Fernandez-Vizarra, E. Assembly of mammalian oxidative phosphorylation complexes I-V and supercomplexes. Essays Biochem. 2018, 62, 255-270. [CrossRef]

99. Wiemer, M.; Osiewacz, H.D. Effect of paraquat-induced oxidative stress on gene expression and aging of the filamentous ascomycete Podospora anserina. Microbial Cell 2014, 1, 225-240. [CrossRef]

100. Borghouts, C.; Werner, A.; Elthon, T.; Osiewacz, H.D. Copper-modulated gene expression and senescence in the filamentous fungus Podospora anserina. Mol. Cell Biol. 2001, 21, 390-399. [CrossRef]

101. Scheckhuber, C.Q.; Wanger, R.A.; Mignat, C.A.; Osiewacz, H.D. Unopposed mitochondrial fission leads to severe lifespan shortening. Cell Cycle 2011, 10, 3105-3110. [CrossRef]

102. Joseph-Horne, T.; Babij, J.; Wood, P.M.; Hollomon, D.; Sessions, R.B. New sequence data enable modelling of the fungal alternative oxidase and explain an absence of regulation by pyruvate. FEBS Lett. 2000, 481, 141-146. [CrossRef]

103. Joseph-Horne, T.; Wood, P.M.; Wood, C.K.; Moore, A.L.; Headrick, J.; Hollomon, D. Characterization of a split respiratory pathway in the wheat "take-all" fungus, Gaeumannomyces graminis var. tritici. J. Biol. Chem. 1998, 273, 11127-11133. [CrossRef]

104. Rogov, A.G.; Sukhanova, E.I.; Uralskaya, L.A.; Aliverdieva, D.A.; Zvyagilskaya, R.A. Alternative oxidase: Distribution, induction, properties, structure, regulation, and functions. Biochemistry 2014, 79, 1615-1634. [CrossRef] [PubMed]

105. Szibor, M.; Gainutdinov, T.; Fernandez-Vizarra, E.; Dufour, E.; Gizatullina, Z.; Debska-Vielhaber, G.; Heidler, J.; Wittig, I.; Viscomi, C.; Gellerich, F.; et al. Bioenergetic consequences from xenotopic expression of a tunicate AOX in mouse mitochondria: Switch from RET and ROS to FET. Biochim. Biophys. Acta Bioenerg. 2020, 1861, 148137. [CrossRef] [PubMed]

106. Saha, B.; Borovskii, G.; Panda, S.K. Alternative oxidase and plant stress tolerance. Plant Signal Behav. 2016, 11, e1256530. [CrossRef]

107. Dat, J.; Vandenabeele, S.; Vranova, E.; Van Montagu, M.; Inze, D.; Van Breusegem, F. Dual action of the active oxygen species during plant stress responses. Cell Mol. Life Sci. 2000, 57, 779-795. [CrossRef] [PubMed]

108. Maxwell, D.P.; Wang, Y.; McIntosh, L. The alternative oxidase lowers mitochondrial reactive oxygen production in plant cells. Proc. Natl. Acad. Sci. USA 1999, 96, 8271-8276. [CrossRef] [PubMed]

109. Minagawa, N.; Koga, S.; Nakano, M.; Sakajo, S.; Yoshimoto, A. Possible involvement of superoxide anion in the induction of cyanide-resistant respiration in Hansenula anomala. FEBS Lett. 1992, 302, 217-219. [CrossRef]

110. Vanlerberghe, G.C.; McLntosh, L. Signals regulating the expression of the nuclear gene encoding alternative oxidase of plant mitochondria. Plant Physiol. 1996, 111, 589-595. [CrossRef]

111. Knuppertz, L.; Warnsmann, V.; Hamann, A.; Grimm, C.; Osiewacz, H.D. Stress-dependent opposing roles for mitophagy in aging of the ascomycete Podospora anserina. Autophagy 2017, 13, 1037-1052. [CrossRef]

112. Esser, K.; Keller, W. Genes inhibiting senescence in the ascomycete Podospora anserina. Mol. Gen. Genet. 1976, 144, 107-110. [CrossRef] [PubMed] 
113. Tudzynski, P.; Esser, K. Chromosomal and extrachromosomal control of senescence in the ascomycete Podospora anserina. Mol. Gen. Genet. 1979, 173, 71-84. [CrossRef] [PubMed]

114. Anisimova, A.S.; Alexandrov, A.I.; Makarova, N.E.; Gladyshev, V.N.; Dmitriev, S.E. Protein synthesis and quality control in aging. Aging (Albany NY) 2018, 10, 4269-4288. [CrossRef] [PubMed]

115. Smith, M.D.; Gu, Y.; Querol-Audi, J.; Vogan, J.M.; Nitido, A.; Cate, J.H. Human-like eukaryotic translation initiation factor 3 from Neurospora crassa. PLoS ONE 2013, 8, e78715. [CrossRef] [PubMed]

116. Siridechadilok, B.; Fraser, C.S.; Hall, R.J.; Doudna, J.A.; Nogales, E. Structural roles for human translation factor eIF3 in initiation of protein synthesis. Science 2005, 310, 1513-1515. [CrossRef]

117. Sun, C.; Todorovic, A.; Querol-Audi, J.; Bai, Y.; Villa, N.; Snyder, M.; Ashchyan, J.; Lewis, C.S.; Hartland, A.; Gradia, S.; et al. Functional reconstitution of human eukaryotic translation initiation factor 3 (eIF3). Proc. Natl. Acad. Sci. USA 2011, 108, 20473-20478. [CrossRef]

118. Shah, M.; Su, D.; Scheliga, J.S.; Pluskal, T.; Boronat, S.; Motamedchaboki, K.; Campos, A.R.; Qi, F.; Hidalgo, E.; Yanagida, M.; et al. A transcript-specific eIF3 complex mediates global translational control of energy metabolism. Cell Rep. 2016, 16, 1891-1902. [CrossRef]

119. Jung, T.; Catalgol, B.; Grune, T. The proteasomal system. Mol. Aspects Med. 2009, 30, 191-296. [CrossRef] [PubMed]

120. Chondrogianni, N.; Gonos, E.S. Proteasome dysfunction in mammalian aging: Steps and factors involved. Exp. Gerontol. 2005, 40, 931-938. [CrossRef]

121. Hershko, A.; Ciechanover, A. The ubiquitin system. Annu. Rev. Biochem. 1998, 67, 425-479. [CrossRef]

122. Murata, S.; Yashiroda, H.; Tanaka, K. Molecular mechanisms of proteasome assembly. Nat. Rev. Mol. Cell Biol. 2009, 10, 104-115. [CrossRef] [PubMed]

123. Shaid, S.; Brandts, C.H.; Serve, H.; Dikic, I. Ubiquitination and selective autophagy. Cell Death Differ. 2013, 20, 21-30. [CrossRef] [PubMed]

124. Taylor, E.B.; Rutter, J. Mitochondrial quality control by the ubiquitin-proteasome system. Biochem. Soc. Trans 2011, 39, 1509-1513. [CrossRef]

125. Karbowski, M.; Youle, R.J. Regulating mitochondrial outer membrane proteins by ubiquitination and proteasomal degradation. Curr. Opin. Cell Biol. 2011, 23, 476-482. [CrossRef] [PubMed]

126. Baek, G.H.; Cheng, H.; Kim, I.; Rao, H. The Cdc48 protein and its cofactor Vms1 are involved in Cdc13 protein degradation. J. Biol. Chem. 2012, 287, 26788-26795. [CrossRef]

127. Kornmann, B.; Currie, E.; Collins, S.R.; Schuldiner, M.; Nunnari, J.; Weissman, J.S.; Walter, P. An ER-mitochondria tethering complex revealed by a synthetic biology screen. Science 2009, 325, 477-481. [CrossRef]

128. Michel, A.H.; Kornmann, B. The ERMES complex and ER-mitochondria connections. Biochem. Soc. Trans 2012, 40, 445-450. [CrossRef]

129. Flis, V.V.; Daum, G. Lipid transport between the endoplasmic reticulum and mitochondria. Cold Spring Harb. Perspect. Biol. 2013, 5, 13235. [CrossRef]

130. Ravanelli, S.; den Brave, F.; Hoppe, T. Mitochondrial quality control governed by ubiquitin. Front. Cell Dev. Biol. 2020, 8, 270. [CrossRef]

131. Vance, J.E. Phospholipid synthesis in a membrane fraction associated with mitochondria. J. Biol. Chem. 1990, $265,7248-7256$. [CrossRef]

132. Dederer, V.; Khmelinskii, A.; Huhn, A.G.; Okreglak, V.; Knop, M.; Lemberg, M.K. Cooperation of mitochondrial and ER factors in quality control of tail-anchored proteins. Elife 2019, 8. [CrossRef] [PubMed]

133. Hansen, K.G.; Aviram, N.; Laborenz, J.; Bibi, C.; Meyer, M.; Spang, A.; Schuldiner, M.; Herrmann, J.M. An ER surface retrieval pathway safeguards the import of mitochondrial membrane proteins in yeast. Science 2018, 361, 1118-1122. [CrossRef] [PubMed]

134. Madreiter-Sokolowski, C.T.; Waldeck-Weiermair, M.; Bourguignon, M.P.; Villeneuve, N.; Gottschalk, B.; Klec, C.; Stryeck, S.; Radulovic, S.; Parichatikanond, W.; Frank, S.; et al. Enhanced inter-compartmental $\mathrm{Ca}^{(2+)}$ flux modulates mitochondrial metabolism and apoptotic threshold during aging. Redox Biol. 2019, 20, 458-466. [CrossRef]

135. Abrisch, R.G.; Gumbin, S.C.; Wisniewski, B.T.; Lackner, L.L.; Voeltz, G.K. Fission and fusion machineries converge at ER contact sites to regulate mitochondrial morphology. J. Cell Biol. 2020, 219. [CrossRef]

136. Friedman, J.R.; Lackner, L.L.; West, M.; DiBenedetto, J.R.; Nunnari, J.; Voeltz, G.K. ER tubules mark sites of mitochondrial division. Science 2011, 334, 358-362. [CrossRef]

137. Ji, W.K.; Chakrabarti, R.; Fan, X.; Schoenfeld, L.; Strack, S.; Higgs, H.N. Receptor-mediated Drp1 oligomerization on endoplasmic reticulum. J. Cell Biol. 2017, 216, 4123-4139. [CrossRef]

138. Perez-Riverol, Y.; Csordas, A.; Bai, J.; Bernal-Llinares, M.; Hewapathirana, S.; Kundu, D.J.; Inuganti, A.; Griss, J.; Mayer, G.; Eisenacher, M.; et al. The PRIDE database and related tools and resources in 2019: Improving support for quantification data. Nucleic Acids Res. 2019, 47, D442-D450. [CrossRef] [PubMed] 